\title{
Hares and rabbits at Regourdou (Montignac-sur- Vézère, Dordogne, France): paleontological and taphonomic studies of two naturally-occurring bone accumulations
}

Lièvre et lapin à Regourdou (Montignac-sur-Vézère, Dordogne, France) : études paléontologique et taphonomique de deux accumulations osseuses d'origine naturelle

Maxime Pelletier, Aurélien Royer, Trenton Holliday and Bruno Maureille

\section{OpenEdition}

\section{Journals}

Electronic version

URL: http://journals.openedition.org/paleo/3029

DOI: $10.4000 /$ paleo.3029

ISSN: 2101-0420

Publisher

SAMRA

\section{Printed version}

Date of publication: 1 December 2015

Number of pages: 161-183

ISSN: 1145-3370

\section{Electronic reference}

Maxime Pelletier, Aurélien Royer, Trenton Holliday and Bruno Maureille, « Hares and rabbits at Regourdou (Montignac-sur-Vézère, Dordogne, France): paleontological and taphonomic studies of two naturally-occurring bone accumulations », PALEO [Online], 26 | 2015, Online since 26 April 2016, connection on 07 July 2020. URL : http://journals.openedition.org/paleo/3029 ; DOI : https://doi.org/ 10.4000/paleo.3029

This text was automatically generated on 7 July 2020.

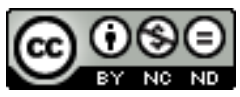

PALEO est mis à disposition selon les termes de la licence Creative Commons Attribution - Pas d'Utilisation Commerciale - Pas de Modification 4.0 International. 


\title{
Hares and rabbits at Regourdou (Montignac-sur-Vézère, Dordogne, France): paleontological and taphonomic studies of two naturally-occurring bone accumulations
}

\author{
Lièvre et lapin à Regourdou (Montignac-sur-Vézère, Dordogne, France) : études \\ paléontologique et taphonomique de deux accumulations osseuses d'origine \\ naturelle
}

Maxime Pelletier, Aurélien Royer, Trenton Holliday and Bruno Maureille

The authors wish to thank the Ministry of Culture and Communication - the Regional Archaeology Service - Aquitaine. Thanks also to Jean-Jacques Cleyet-Merle, director of the Musée National de Préhistoire, who has allowed us access the Regourdou, Lunel-Viel and Combe-Grenal materials. We are also thanking Jean-Baptiste Mallye, Myriam Boudadi-Maligne and JeanChristophe Castel for access to the Igue du Gral collection (Lot), Evelyne Crégut-Bonnoure for that of Coulet des Roches (Vaucluse), Emmanuel Robert of the Claude-Bernard University in Lyon for that of Jaurens (Corrèze), Cécile Callou for the modern populations of the MNHN and JeanPhilip Brugal for those of Igue des Rameaux, Les Canalettes and Coudoulous 1 and 2. We are also thanking Eugene and Marie-Françoise Bonifay, Bernard Vandermeerch, Stéphane Madelaine, Alain Turq and all the members of the scientific team for their support and the many discussions around Regourdou. Finally, we wish to thank Emmanuel Desclaux and David Cochard for their valuable comments that have allowed improving this study. This work received support from the French Government program Investissements d'avenir in the context of the $A^{*} M I D E X$ project bearing the reference "ANR-11-IDEX-0001-02" and the LabEx Archaeological Sciences Bordeaux, a program funded by the ANR - $n^{\circ}$ ANR-10-LabX-52, NeMo project. 


\section{Introduction}

The fillings in karst formations in the broad sense yield numerous faunal remains, from large mammals to small vertebrates such as leporids (Lagomorpha; Mammalia). These are found in paleontological and archaeological sites, and can, in some cases, dominate the faunal spectra in many Palaeolithic and palaeontological sites in Western Europe. The study of these skeletal remains then provides insights into the behaviour of prehistoric societies or animal communities. Indeed, leporids have regularly been exploited for food during the Upper Palaeolithic in Western Europe (Alhaique 1994; Brugal 2006; Cochard 2004a; Fontana and Chauvière 2007; Hocket and Bicho 2000; Pérez Ripoll 1993, 2004; Sanchis -Serra 2010, 2012), some sites even suggesting this exploitation as early as the Lower (Blasco and Fernandez Peris 2012; Desclaux 1992; El Guennouni 2001) and Middle Palaeolithic (Cochard et al. 2012; Defleur et al. 1994; Gerber 1973; Hardy et al. 2013 ; Huguet-Pàmies 2007; Maul 2014; Morin 2012; Sanchis-Serra and Fernández Peris 2008). Criteria used to highlight the exploitation of this small game by Man are the location and recurrent aspect of butchery and burnt traces on the bones (Vine and Marinval-Vine 1983; Vigne et al. 1981) and a large number of shaft cylinders from the long bones of the limbs (Hockett 1991).

2 But during the Pleistocene, some carnivores mainly occupied karst cavities, as well as human groups, and traces of their activities can then be combined (Binford 1981; Brain 1981; Payne 1983; Stiner 1994). Thus, to reconstruct the taphonomic history of a deposit from the bone assemblage, it is necessary to distinguish the different agents responsible for these accumulations, knowing that leporids are the staple diet of many predators (Delibes and Hiraldo 1981). An accumulation generated by non-human predators (terrestrial carnivores, diurnal and nocturnal raptors) can be identified using a number of taphonomic criteria such as teeth or digestion marks (Cochard 2007 - tab.1, p.469; Lloveras, Moreno-Garcia, Nadal 2012- tab. 9, p. 588). Thus many reference documents have been established to distinguish between predators such as the Coyote (Schmitt and Juell 1994), the Fox (Sanchis-Serra 2000; Cochard 2004b; Lloveras, MorenoGarcia, Nadal 2012), the Badger (Mallye, Cochard, Laroulandie 2008), the Iberian Lynx (Lloveras, Moreno-Garcia, Nadal 2008a;. Rodriguez-Hidalgo et al. 2015), the Golden Eagle (Hockett 1995, 1996; Schmitt 1995), the Spanish Imperial Eagle (Lloveras, MorenoGarcia, Nadal 2008b), the Eagle Owl (Sanchis-Serra 2000; Cochard 2004c; Lloveras, Moreno-Garcia, Nadal 2009; Yravedra Sainz de los Terreros 2006) or other birds of prey (Hockett 1989, 1991, 1995; Cruz-Uribe and Klein 1998).

3 It is also important to note that leporids have their own ethological characteristics (e.g. burrowing for rabbits) that may involve an in situ natural mortality within these cavities. This may result from a type of attritional mortality stipulating the presence of burrows in the assemblage, but this may also be caused by an accidental type of mortality, following a pitfall trap context (Cochard 2004a). In the first case, this phenomenon is limited to the Oryctolagus genus (rabbit) since it is the only leporid with burrowing and sedentary behaviour. In fact, it opposes the latter that characterizes the Lepus genus (hare), occupying larger territories and therefore with greater mobility, especially for young adults (Cochard 2007).

4 According to the mechanisms and agents that created the deposit, it is possible to answer various questions that may be related to archaeozoology, climatic and 
paleoenvironmental conditions, or to the history and integrity of the site. Despite the creation of reference documents, the exact identification of the agent responsible for a natural accumulation of leporids on a site is difficult, as many taphonomic criteria are common among the different accumulating agents, unlike the accumulations of anthropogenic origin, relatively easier to identify (Cochard 2007; Cochard 2008; Lloveras, Moreno-Garcia, Soler 2010).

5 Furthermore, in fossil context, a leporid assemblage may be the result of a succession of events generated by one or more accumulating agents. "One criterion is [therefore] not sufficient [nor] to recognize the origin of the creation of a taphocoenosis" (Cochard 2004a - $\mathrm{p}$. 288) nor to distinguish the contribution of several mechanisms and agents causing the formation of the bone stock. It is therefore essential to cross-reference the taphonomic data (skeletal representation, breakage, degree of ossification or macro traces) with the various contextual data available such as spatial distribution or the presence of fossil burrows (Cochard 2004a).

6 In the context of the Middle Palaeolithic, in which evidence of the exploitation of leporids by humans are frequent, the question legitimately arises for the Regourdou deposit (Montignac-sur-Vézère, Dordogne), a site that yielded a Neandertal skeleton and Mousterian lithic artefacts. The highly abundant fauna is clearly dominated by brown bear (Bonifay 1989) and leporids. In the present paper, we are offering new elements for discussion about the function and the history of the cave, from a paleontological and taphonomic study of the leporid remains. Our aim is to determine the mechanisms that created a significant accumulation of bone remains, in a context in which the assumption of an accumulation of large mammals by Neandertal is debated (Cavanhié 2010). Several species of leporids have been identified within this collection, each with eco-ethological characteristics of their own; the question is raised of the contribution of several mechanisms at the origin of this accumulation, which may differ according to the considered taxa.

\section{1 - Regourdou}

7 The Regourdou site is located by the town of Montignac-sur-Vézère in the Dordogne (fig. 1), on the left bank of the Vézère River, on top of a hill near the Lascaux cave. This is a karst cavity opening up in Santonian limestone (Upper Cretaceous), whose roof, still present in the Palaeolithic, collapsed on the sedimentary infill. In 1954, the landowner, R. Constant, began underground work in front of the entrance of his house. For this, he began to dig the sediment clogging the karst, interpreted later by E. Bonifay as the only access to the Regourdou cave in the Palaeolithic (Bonifay et al. 2007). The Mousterian deposit was discovered during this work, finally allowing him to obtain an excavation permit in 1957. On the night of September 22 to 23, 1957, the almost complete skeleton of an adult Neandertal was unearthed. Field operations at Regourdou were then entrusted to E. Bonifay in 1961, until the last campaign in 1964. All the work done between 1954 and 1964 significantly changed the morphology of the site that is today a vast depression, $23 \mathrm{~m}$ long, $11 \mathrm{~m}$ wide and between 4 and $6.7 \mathrm{~m}$ deep. The excavations conducted by E. Bonifay focused mainly on the western part of the cave between 1961 and 1963, then on the eastern part in 1964, for a total excavated area of around $55 \mathrm{~m}^{2}$. The remains were coordinated using an orthonormal Cartesian scaling system, sometimes by group of remains and by following the lithological layers defined 
by E. Bonifay. Sieving of sediments does not appear to have been systematic with, for example, a "collection of microfauna [...] done layer by layer, mainly during the summer of 1964 " (Simard 1968 - p. 1437), that is to say during the last excavation campaign. The sediments were then dry-sieved with 2 and $1 \mathrm{~mm}$ sieves.

The filling of the Regourdou cave is complex, particularly because of numerous collapses of the roof and/or walls (Bonifay 1964). According to E. Bonifay, the stratigraphy of the Regourdou filling is subdivided into 10 lithological layers (fig. 2), mainly on the basis of the colour of the sands, which are one of the elements of the sedimentary filling. The layers 8 to 3 correspond to the first assemblage that was attributed the Würm I or stage 5 of the Marine Isotope Stage (MIS 5), while the second assemblage consisting of layer 2, is associated to the Würm 2 (that is to say the MIS 4) (Bonifay et al. 2007). Layer 1 is the collapsed roof of the cave. Based on the large herbivore fauna, layer 4 was attributed to the MIS 5 with a rather temperate fauna characterized by the presence of Cervus simplifidens, while layer 2 was associated with the MIS 4 because of its "typically cold" characteristic with the dominant presence of the reindeer (Delpech 1996). The study of small mammals highlights a relatively dry climate in the layer 8 with steppe tendency (see steppe pika, Ochotona pusilla) progressing to a temperate and humid climate in layers 7, 6, 5 and 4, which are characterized by the presence of the beaver, the bank vole, the wood mouse and the common and crowned shrew. In contrast, layers 3 and 2 are constituted by associations of small mammals reflecting dry climates with the European snow vole and steppe lemming (Simard 1968). Carnivores widely dominate the faunal spectrum making about $70 \%$ of the determinate material, with an omnipresence of brown bear (93\% of carnivore remains) all along the stratigraphic sequence. The wolf and cave hyena are found principally within the lower sequence (layers 5 to 3 ) while the lion seems to have occupied the cave during the setting up of the upper levels (layers 3 and 2) (Cavanhié 2010).

9 The Regourdou site was interpreted by E. Bonifay as a highly symbolic place where the interest of humans for the bear would have been omnipresent, without having ever been a living site due to the scarcity of the lithic material (Bonifay 2002). According to him, Neandertals practiced funerary gestures towards one of their dead by associating several brown bear bones. The presence in the cave of a nearly complete skeleton of a young adult individual is considered as one of the oldest Mousterian burials in Europe (Maureille and Vandermeersch 2007). The study of ursids suggests, because of the presence of cut marks on their remains, that they were skinned to recover the furs (Bonifay 1989). In contrast to this first scenario, recent taphonomic analyses on ursids suggest that the presence of most carcasses in the cave is of natural origin (Cavanhié 2010). Indeed, this study suggests that the cave:

1. mainly functioned as a bear den, with an attritional type of natural mortality for brown bears, dominated by the presence of juveniles and sub-adults and the presence of scavenging traces on the bones;

2. could have been a pitfall trap configuration, with a natural accidental supply of herbivores remains;

3. suggests a "fragile" archaeo-stratigraphy given the large number of pairing, connections and re-fittings (intra and inter-layer) done. The hypothesis of an anthropogenic intervention is only supported by the small proportion of bones: 27 remains of reindeer in layer 2 show traces of intentional fracturing, four herbivore remains show cut marks in 
layers 8, 7 and 2 and only three remains of ursids show striations that may suggest human exploitation (Cavanhié 2010).

Figure 1 - Location of the sites mentioned in the text. ( Géoatlas.

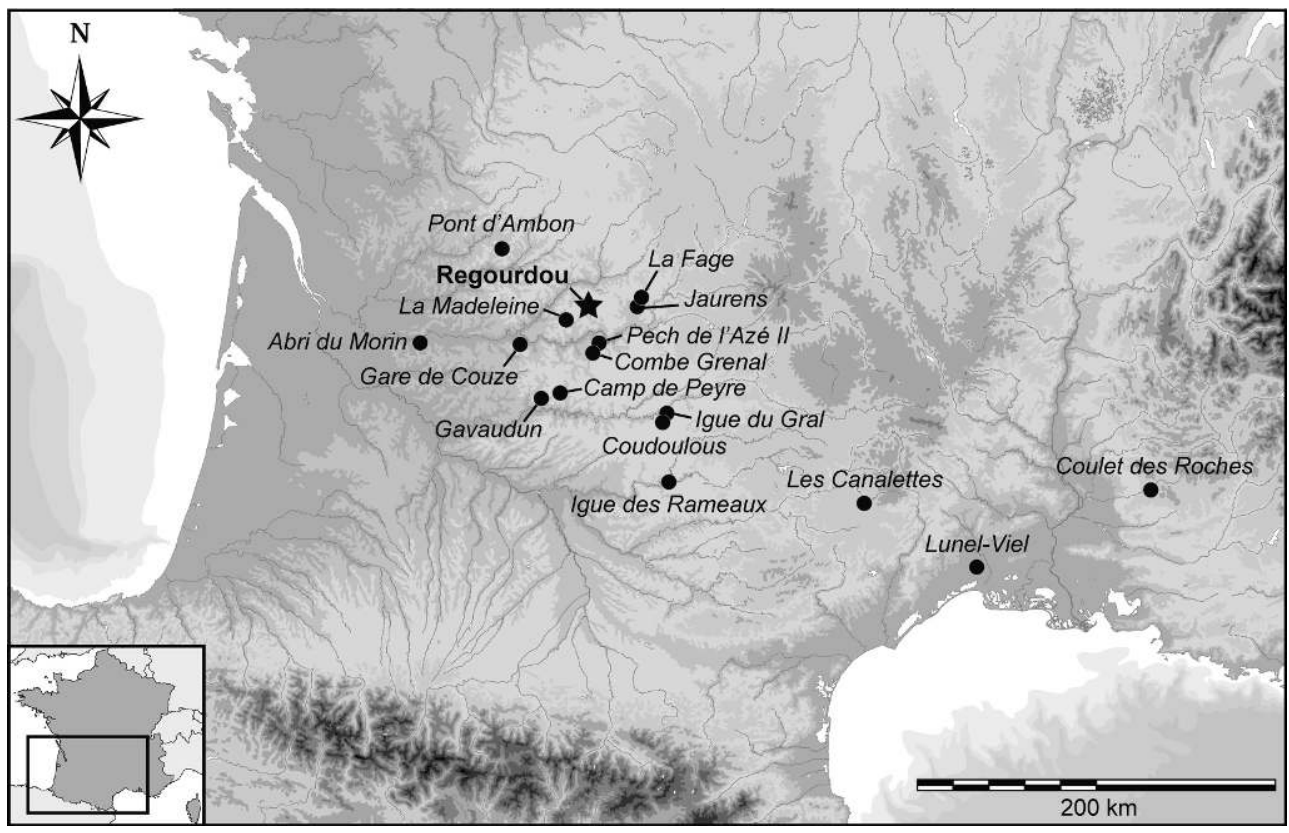

Figure 2 - Stratigraphy of Regourdou Cave (modified from Bonifay E. 2002).

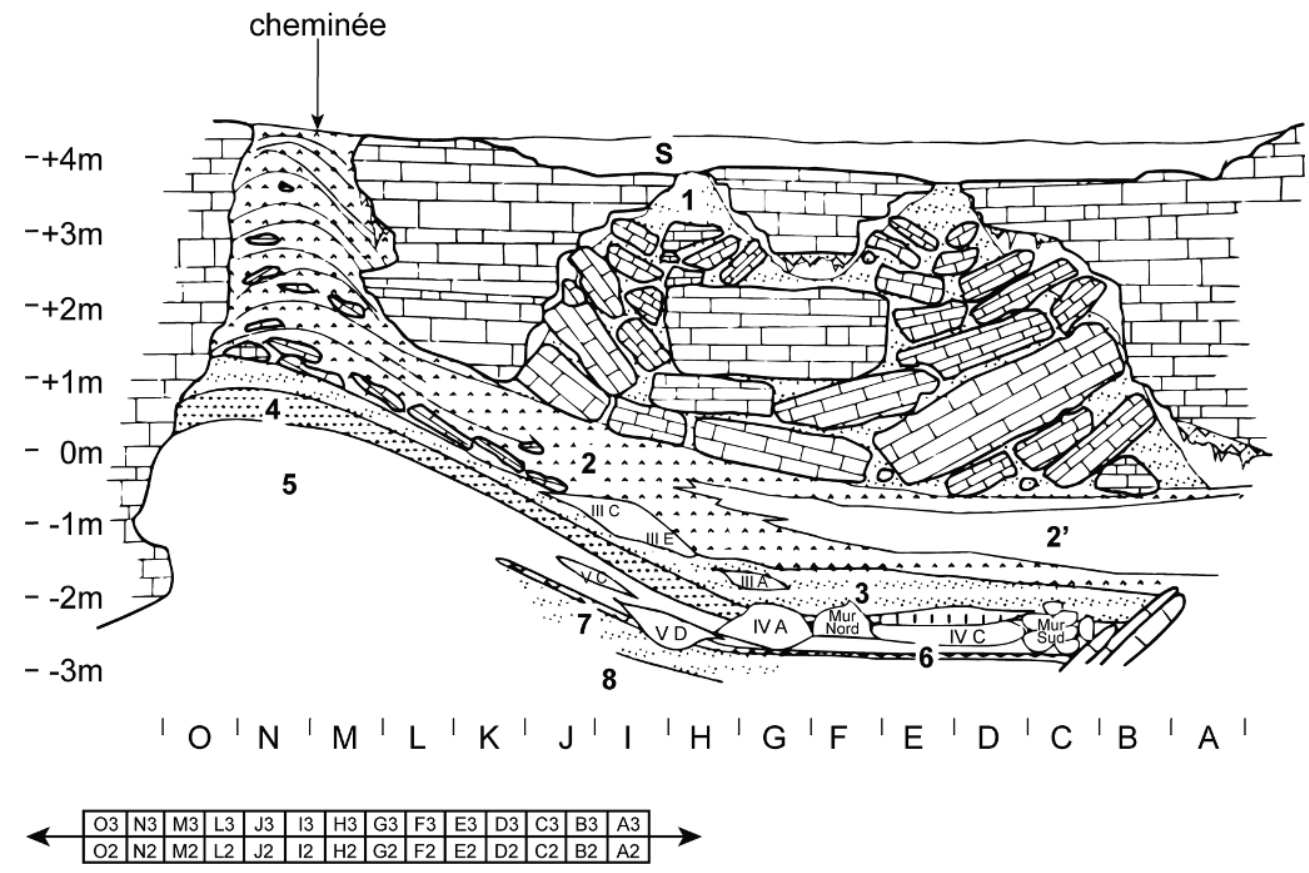




\section{2 - Material and methods}

\section{1 - Leporid remains and taxonomic identification}

10 The study of the Regourdou leporids focuses on the analysis of hares and rabbits, distinguishing these two taxa, each with its own ethological and ecological features. The European rabbit is a small animal $(38-53 \mathrm{~cm} ; 1-2 \mathrm{~kg})$, burrowing and sedentary, with a very complex social organization, living in groups of several dozen individuals. It is predisposed to adapt to rather varied environments. In contrast, the mountain hare is larger (45-61 cm; 2-6 kg). It is a solitary animal that occupies large territories and lives in a rather cold climate in both rocky environments and mixed forests (Maurin and Haffner 1995). These features lead us to consider both species separately. In order to determine specifically the different taxa potentially found in Regourdou, the present study uses simultaneously the morphological and biometric characteristics of the teeth (Donard 1982; Koby 1959; Morel and Müller 1997).

11 Leporid remains analysed in this study come from the Bonifay excavations, kept in the National Museum of Prehistory. This collection consists at a minimum of over 10,000 bone fragments collected on the entire stratigraphic sequence. This estimate does not include the material still remaining unwashed or unsorted to this day. Among these remains, only 131 were coordinated by E. Bonifay during his excavations. This low number of coordinated objects in relation to their abundance and the high determination rate (99\%), obtained from the remains, suggests the presence of bias in the creation of this collection of leporids. Presumably, the bones collected during the excavation underwent selective sorting, especially in favour of the most characteristic pieces for some layers, as shown by the inequalities in the relationship between the Minimal Number of Individuals and the Number of Skeletal Parts (tab. 1). As underscored by D. Cochard (2004a - p. 67), the selective collection of leporids skeletal elements may be due to the "skill and care of the excavator, (to) the interest of the excavated area, [to] the nature the sediment, [to] the identification of the object, [and to] the outstanding characteristics of the remain."

12 A total of 3,175 remains were analysed for the entire sequence. The Minimum Number of Individuals (combined MNI) in Regourdou, calculated using the distal end of the humerus, is 91 , out of which 58 are rabbits and 33 hares, on the entire sequence. Due to the small number of remains, layers 5 to 7 were not included in this study. Layers 2 and 3 are relatively poor in number of remains, only layers 8 -rich in rabbit remains - and 4 - rich in hare remains - have been the subject of a more detailed study with an analysis of the mortality and skeletal profiles, especially with the calculation of the percentage of relative abundance.

\section{2 - Bone surface and fracturing}

13 In order to distinguish between accumulations from natural deaths and those related to predation, biotic and abiotic modifications in bone surfaces have systematically been recorded. The nature of the bone at the time of fracturing was also recorded by following the classification method proposed by Villa and Mahieu (1991). In addition, correlations between the percentage of relative abundance of the various elements and 
their bone density in $\mathrm{g} / \mathrm{cm}^{3}$ were calculated after Pavao and Stahl (1999) in order to check for bias due to differential preservation.

\section{3 - Mortality profile}

14 The mortality profile was established from the degree of ossification of the long bones of the limbs. In rabbits, adult size and sexual maturity are reached as early as five months old (Biadi and Le Gall 1993), but all the epiphyses are fused only from the age of nine months (Jones 2006). Thus, three age classes can be distinguished: "juvenile" (<3 months), when no epiphysis is fused; "sub-adult" (between five and nine months), adult in size but with epiphyses in the process of being ossified; and "adults" (>9 months) with all epiphyses fused. Concerning the hare, individuals are considered adults from 11 months and juveniles before four months (Cochard 2004a). These analyses of the degree of ossification were carried out on the five long bones of the skeleton (humerus, radius, ulna, femur and tibia). Since methods to identify age classes from elements such as vertebrae, ribs or phalanges do not exist, to the best of our knowledge, these will not be taken into account in the analyses.

Table 1 - Complete distribution of leporid remains of Regourdou by level

\begin{tabular}{|r|rrr:rrc|}
\hline & \multicolumn{5}{c|}{ Lapin } & \multicolumn{4}{c|}{ Lièvre } \\
couche 2 & 4 & 2 & 0,50 & 37 & 5 & 0,13 \\
couche 3 & 99 & 14 & 0,14 & 83 & 12 & 0,14 \\
couche 4 & 23 & 3 & 0,13 & 292 & 8 & 0,03 \\
couche 5 & 7 & 3 & 0,43 & 4 & 2 & 0,50 \\
couche 6 & - & - & - & - & - & - \\
couche 7 & 12 & 3 & 0,25 & 1 & 1 & 1,00 \\
couche 8 & 2565 & 33 & 0,01 & 48 & 5 & 0,10 \\
Total & 2710 & $\mathbf{5 8}$ & - & 465 & 33 & - \\
\hline
\end{tabular}

\section{4 - Sexual dimorphism}

15 In contrast, the sex ratio was not established on the fossil population of Regourdou. Indeed, one of the rare sex determination models proposed by E.L. Jones (2006), based on the ratio of the transverse diameter of the distal epiphysis of the humerus and the width of the trochlea, does not work systematically. By reproducing the same analyses on the similar current populations from the National Museum of Natural History in Paris, very different results were obtained, preventing its application to the fossil material (fig. 3). Sex determination, well-marked in the previous study, is not apparent in our study, for which there is no difference between the two resulting groups (ANCOVA test, gradient $p=0.94$; original ordinate $p=0.65$ ). These differences can certainly be explained by the existence of an inter-observer bias in the measurement of such small bones. 


\section{5 - Body size and morphometry}

16 and Oryctolagus genera in the Pleistocene fossil assemblages (i.e. Donard 1982; Pelletier et al. 2015). It was also highlighted that the size of leporids varies depending on climatic conditions according to Bergmann's rule, for both the rabbit (Callou 2003) and the mountain hare (Angerbjörn and Flux 1995). Indeed, there is currently a latitudinal variation in the size of wild rabbit populations in which the larger size populations are mostly located at higher latitudes (Callou 2003; Sharples et al. 1996). Thus a linear regression could be established between the bone size of the current rabbits and the temperature of the environment (Davis and Moreno-Garcia 2007). This relationship applied to sites of southern France and northern Spain showed latitudinal climatic gradients during the Late, Middle (El Guennouni 2001) and Lower (Pelletier et al. 2015) Pleistocene. As the body size of leporids highly depends on their geographical location and on climatic variations, comparing individuals from Regourdou with various geographically close fossil populations allows to distinguish what belongs to global climate variations from what concerns local populations' characteristics. The body size of the Regourdou individuals was estimated by two methods. The first method is based on measurements of the transverse diameter (TD) of the distal epiphysis of the humerus and the total length (totL) of the calcaneus (von den Driesh 1976). These measurements were compared with data published by Donard (1982) from 8 Pleistocene deposits of Southwestern France (Abri du Morin, Camp de Peyre, Gavaudun, Gare de Couze, La Fage, La Madeleine, Pech de l'Azé 2 and Pont d'Ambon) and with unpublished personal data from the five following Pleistocene deposits: Combe-Grenal, Coudoulous 1 , Coudoulous 2, Igue des Rameaux and Igue du Gral.

The second method uses two-dimensional geometric morphometrics and is based on the analysis of the landmarks' configuration (Bookstein 1991) following the protocol developed by Patnaik (2002) and De Marfà (2009) and amended by Pelletier et al. (2015). These analyses are carried out on the third lower premolar (p3), which is the tooth showing the highest degree of specific differentiation in leporids. The digitization of the landmarks was done from pictures using the tpsDig2 program (thin plate splines; @2005 Rohlf) and then compiled with tpsutil (๔ 2005 Rohlf). A Principal Component Analysis (PCA), using the tpsRelw software (๔ 2005 Rohlf) was then carried out. To ensure the reproducibility of our analysis, the $\mathrm{p} 3$ were fixed vertically to the camera lens in order to standardize all the shots. The reference points correspond to maximum curvature points (fig. 4A). The p3 of the Regourdou leporids were compared with those of two reference sources. The first reference source is formed by the $\mathrm{p} 3$ of modern rabbit individuals $(\mathrm{N}=51)$ and of hares $(\mathrm{N}=13)$ from four locations. The second reference source is made up of the $\mathrm{p} 3$ of fossil rabbit individuals $(\mathrm{N}=214)$ and mountain hares $(\mathrm{N}=83)$ from 11 fossil sites dated between the MIS 11-10 and the MIS 2 (tab. 2). 
Figure 3 - Biometric relation between transverse diameter (DT) of the distal epiphysis of the humerus and trochlear breadth ( $L$ troc) of individual leporids from the Muséum National d'Histoire Naturelle de Paris. A: from Jones 2006; B: Personal data.
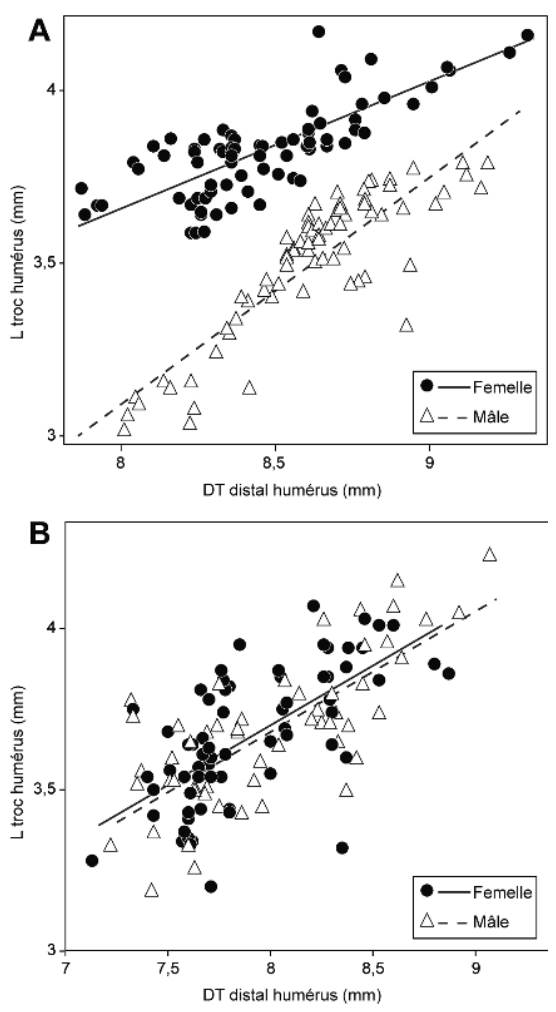

\section{3 - Results}

\section{1 - Taxonomic identification}

Prior to this research, two paleontological studies have focused on the lagomorphs from Regourdou. The first one by Simard (1968) highlights the presence of the European rabbit (Oryctolagus cuniculus), the European hare (Lepus europaeus) and the steppe pika (Ochotona pusilla). The second study by Donard (1982) only concerns leporids of layer 4 and identifies an exclusive presence of the mountain hare (Lepus timidus). In contrast, our work highlights the presence of the rabbit and the mountain hare (fig. 4). The rabbit is characterized by a third lower premolar with a rather subtriangular occlusal surface. The lingual and vestibular anteroconids are similar in sizes and shapes, separated by a relatively deep anteroflexid, and the protoflexid forms an angle of $90^{\circ}$ or more. For the mountain hare, the vestibular anteroconid is more developed than the lingual anteroconid, with a shallow anteroflexid. This tooth does not have any marked paraflexid and the angle of the protoflexid is always inferior to $90^{\circ}$. Thus, no dental remain of European hare has been determined. Note that specimens of 0 . pusilla are also kept in this collection, but they have not been the object of analysis for this study. Despite the presence of specimens of both taxa (L. timidus and 0. cuniculus) on the entire stratigraphy (see tabl. 1), both assemblages differ in their amounts of remains: layer 4 mainly consists of remains of mountain hares and layers 8 and 3 of remains of rabbits. 
Figure 4 - Drawings of leporid left inferior third premolars (p3). A: Dental terminology (following Palacios and López-Martínez 1980) and location of 9 landmarks (modified from Pelletier et al. 2015); B: Oryctolagus cuniculus (MNHN-2001-37); C: Lepus europaeus (MNHN-1966-232); D: Lepus timidus (MNHN-2009-263); E-F: Oryctolagus cuniculus from Regourdou level 3; G-J: Oryctolagus cuniculus from Regourdou level 8; K-L: Lepus timidus from Regourdou level 3; M-N: Lepus timidus from Regourdou level 4; O-P. Lepus timidus from Regourdou level 8.

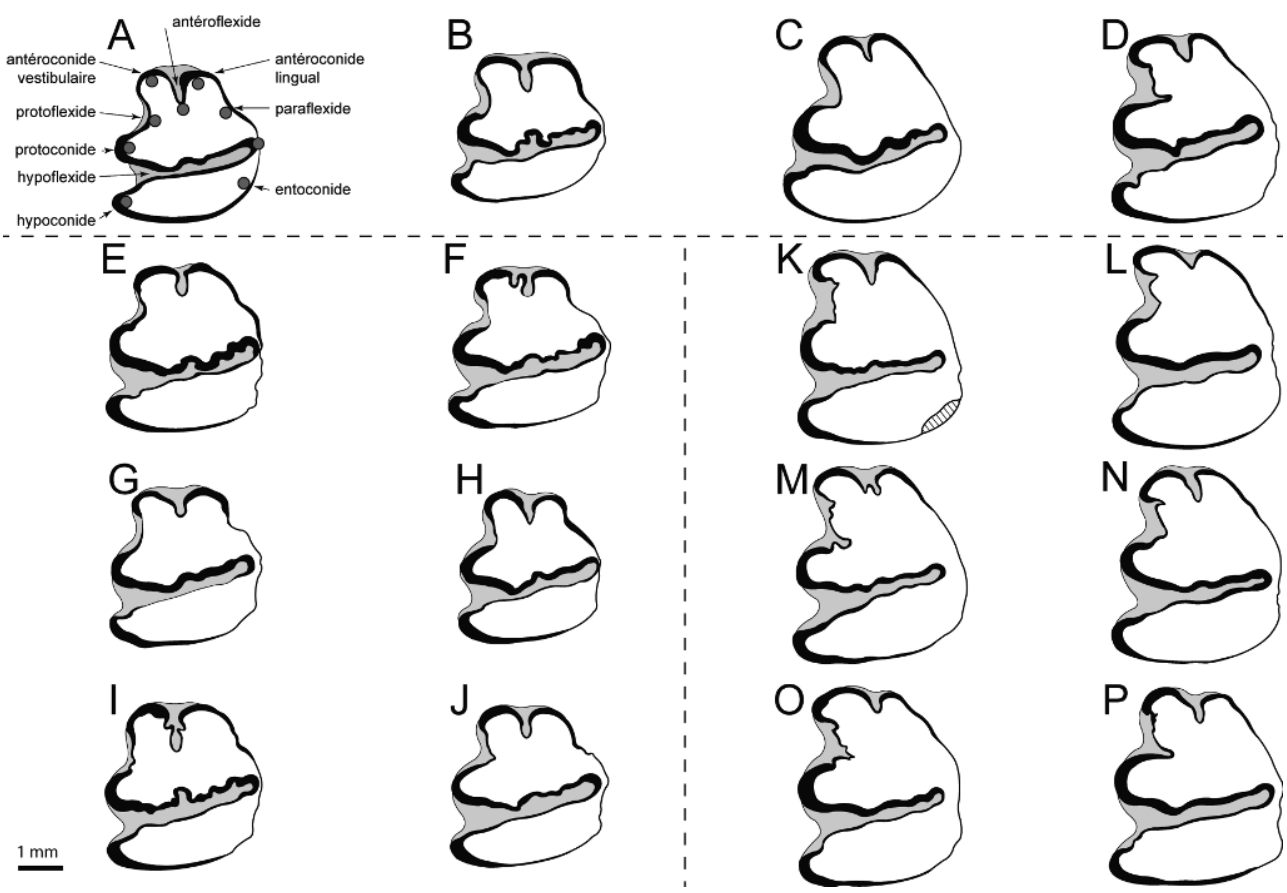

Table 2 - Detailed information on the specimens used in the 2D geometric morphometric study. MNP. Muséum National de Préhistoire, Eyzies-de-Tayac ; LAMPEA: Laboratoire Méditerranéen de Préhistoire Europe Afrique, Aix-en-Provence; PACEA: de la Préhistoire à l'Actuel, Culture,

Environnement, Anthropologie, Talence; MNHN: Muséum National d'Histoire Naturelle, Paris; Requien: Muséun Requien, Avignon; UCBL: Université Claude-Bernard, Lyon. References: F94, Fosse 1994 ; C06, Coumont 2006; JE05, Jeannet 2005; R90, Rouzaud et al. 1990; JA05, Jaubert et al. 2005; DP95, Delpech et Prat 1995 BJ06, Brugal et Jaubert 2006; V87, Valladas et al.1987; G79, Guérin et al. 1979; C08, Castel et al. 2008; CB14, Crégut-Bonnoure et al. 2014; S09, Szmidt et al. 2009; L12, Langlais et al. 2012; B64, Bonifay 1964;

\begin{tabular}{|c|c|c|c|c|c|c|}
\hline Période & Site, département & Conservation & Chronologie & Références & Taxon & $\mathrm{N}$ \\
\hline \multirow[t]{4}{*}{ Pléistocène moyen } & Lunel-Viel, Hérault & MNP & MIS 10-11 & F94 & O. cuniculus & 45 \\
\hline & \multirow[t]{2}{*}{ Igue des Rameaux, Tarn-et-Garonne } & \multirow[t]{2}{*}{ LAMPEA } & Mis 9-10 & C06, JE05, R90 & O. cuniculus & 48 \\
\hline & & & & & $\begin{array}{l}\text { L. timidus } \\
\text { O. cuniculus }\end{array}$ & $\begin{array}{r}2 \\
45\end{array}$ \\
\hline & Coudoulous 1, couche 7, Lot & LAMPEA & Mis 6 & JA05 & L. timidus & 4 \\
\hline \multirow{14}{*}{ Plêistocéne supérieur } & Combe Grenal, couche $57-59$, Dordogne & $\overline{M N P}$ & $\operatorname{Mis} 6$ & DP95 & O. cuniculus & 8 \\
\hline & Coudoulous 2, couche 4, Lot & LAMPEA & MIS 4 & BJ06, C06 & L. timidus & 24 \\
\hline & Les Canalettes, couche 4. Aveyron & LAMPEA & MIS 4 & V87 & O. cuniculus & 46 \\
\hline & Jaurens, Corrèż & UCBL & Mis 3 & G79 & L. timidus & 3 \\
\hline & \multirow{2}{*}{ Igue du Gral, Lot } & \multirow{2}{*}{ PACEA } & \multirow{2}{*}{ MIS 2} & \multirow{2}{*}{$\cos$} & O. cuniculus & 6 \\
\hline & & & & & L. timidus & 24 \\
\hline & Coulet des Roches, Vaucluse & Requien & MIS 2 & CB14 & L. timidus & 26 \\
\hline & Abri du Morin, Gironde & PACEA & MIS 2 & S09, L12 & O. cuniculus & 12 \\
\hline & Abri Murat, Lot & PACEA & Mis 2 & L12 & O. cuniculus & 4 \\
\hline & \multirow[t]{2}{*}{ Regourdou, couche 8, Dordogne } & \multirow[t]{2}{*}{ MNP } & \multirow[t]{2}{*}{ MiS 5d-5a } & \multirow{2}{*}{ B64 } & O. cuniculus & 24 \\
\hline & & & & & L. timidus & 5 \\
\hline & & mover s y & Thio volva & Do4 & O. cuniculus & 4 \\
\hline & Regourdou, couche 3, Dordogne & MNP & MIS 5d-5a & B64 & L.timidus & 9 \\
\hline & Regourdou, couche 2, Dordogne & MNP & MIS 4 & B64 & L.timidus & 3 \\
\hline \multirow[t]{4}{*}{ Populations actuelles } & Tour du Valat, Bouches-du-Rhone & \multicolumn{3}{|l|}{$\overline{\mathrm{MNHN}}$} & O. cuniculus & 20 \\
\hline & Roissy, Val d'Oise & \multicolumn{3}{|l|}{ MNHN } & O. cuniculus & 31 \\
\hline & France, Apes & \multicolumn{3}{|l|}{ Requien } & L. timidus & 8 \\
\hline & France & \multicolumn{3}{|l|}{ MNHN } & L.timidus & 5 \\
\hline
\end{tabular}




\section{2 - The mountain hares of layer 4}

19 Mountain hares in layer 4 are represented by 292 identified remains (tab. 3) corresponding to a minimum number of individuals of eight, estimated from the coxal bone. The analysis of age classes from the degree of ossification of the long bones of the skeleton (humerus, radius, ulna, femur and tibia) indicates the presence of at least 3 adult individuals ( $>11$ months), four sub-adults (5-10 months) and a juvenile (<4 months) (tab. 4).

Regarding the skeletal representation of the mountain hares in layer 4 , all the elements are present in the sample with the exception of some small elements (metacarpal I, carpal, distal phalanges), suggesting that all carcasses have been introduced whole, at least in part, into the cave (fig. 5). The axial skeleton is the anatomical part best represented (33\%), ahead of the long bones of the hind (31\%) and fore (23\%) limbs. However, cranial elements are underrepresented (9\%), as well as phalanges. The bony elements of the skeleton of L. timidus are on average poorly preserved (33\%), although this varies according to the anatomical parts considered. For example, the long bones of the limbs, the scapula and the coxal bone have survival percentages between $62 \%$ and $81 \%$, while the axial skeleton survival percentages are more heterogeneous with high values for the lumbar vertebrae (52\%) and the sacrum (63\%) and low values for the thoracic (8\%) and cervical (20\%) vertebrae. Regarding the preservation of bony parts, the long bones are characterized by an over-representation of the epiphysis (proximal $=74 \%$; distal $=55 \%)$ in relation to the shaft elements $(29 \%)$. Scapular and pelvic girdles are respectively represented by the glenoid cavity (> 83\%) and the region of the acetabulum $(>72 \%)$. The skeletal representation may be biased by a number of factors affecting the carcasses after they entered the cave. However, the correlation between the survival percentage of the various elements and their bone density is not significant $(r=0.61 ; p>0.05)$, which allows one to exclude the role of differential preservation processes.

21 The assemblage shows a relatively low fracturing of skeletal elements with a calculated percentage of complete bones of $58 \%(n=24)$ and a high MNE/NISP ratio (0.85) that confirms this tendency (Hockett and Haws 2002). However, the breakage does not seem homogeneous and particularly affects the long bones of the anterior and posterior limbs and the girdles (tab. 3). Small elongated elements such as metapodials are little affected by breakage, while the tarsals and phalanges are always whole. Despite their apparent fragility, the vertebrae are also well preserved. As for the cranial elements, rare in the assemblage, they are never intact. The vast majority of the fractures affecting the mountain hare assemblage of layer 4 correspond to recent breakage (59\%), probably caused during the excavation and/or the packaging. This breakage particularly affects the most fragile bones such as the girdles and the mandibles, and to a lesser extent the diaphyses of ulna and radius. About $22 \%$ of the material is associated with a phenomenon of breakage on dry bones, with transverse fracture edges and right angles, suggesting the impact of post-depositional modifications.

The bone surfaces are very well preserved. Only $13 \%$ of the material exhibits fine parallel cracks that reflect a phenomenon of "weathering" on the bones (fig. 6A). Parallel micro-striations suggesting a phenomenon of abrasion and/or transport were also found on the proximal end of a radius (fig. 6B); the traces caused by biological agents are anecdotal (NISP=2). A distal end of a femur and a distal end of tibia have 
small "puncture"-like indentations from a carnivore, which can be attributed to secondary scavenging by a small terrestrial predator. None of the traces on the hare element can be attributed to an intervention by humans in this assemblage (cutmarks, burns, shaft cylinders)

\section{3 - The rabbits from Layer 8}

23 The assemblage of rabbit bones from layer 8 consists of 2,565 identified remains (tab. 5) from at least 33 individuals. Unlike the mortality profile of the mountain hares from layer 4, the analysis of the degree of ossification of the long bones of the limbs (tab. 6) suggests that the proportions of juveniles ( $<3$ months), sub-adults ( $4 / 8$ months) and adults ( $>9$ months) are almost equivalent with 11,12 and 10 individuals, respectively.

Except for the metacarpal I and the carpals, all elements are present in the assemblage, indicating that the skeletons were complete at the time of their deposition in the site. The best represented anatomical part is the axial skeleton at $31 \%$. However, differences are observed for the rest of the post-cranial skeleton as the elements of the posterior limbs are relatively more numerous (24\%) compared to the forelimb elements (16\%) and the phalanges (14\%). Teeth (525 remains) are usually implanted in the mandible and maxilla.

If we put aside these last counts, cranial elements are present at $15 \%$ of the assemblage. Rabbit skeletons in layer 8 in Regourdou show moderate conservation with on average about $48 \%$ preserved anatomical elements, despite significant variation between anatomical parts. This varies especially according to age classes (fig. 7). Concerning juveniles, the considered anatomical elements are on average much less well preserved (36\%) than in sub-adults (61\%) and adults (81\%). The femur (82\%), the humerus (77\%) and the coxal bone (59\%) are the best preserved elements in very young individuals. All the other elements have a poor conservation $(>50 \%)$ with a very poor preservation of small elements, such as metapodials or cranial elements. In sub-adults, the calcaneus (96\%), the femur (88\%) and the humerus (83\%) are the best preserved elements. As for the leg extremities, they have a much better conservation than in juveniles. For adults, all elements show a conservation greater than $75 \%$, except for the metacarpals. Regarding the bone parts represented in the assemblage (fig. 8), the epiphysis of the long bones of the limbs are generally better represented than shaft portions, whatever the age classes. The differences between each bone part, for these ten anatomical elements, could be explained by their greater density (Pavao and Stahl 1999). Nevertheless, the absence of correlation between the frequency of these bone parts and their density $(R=0.27 ; p>0.05)$ suggests a limited impact of a differential conservation on the skeletal representation of the sample.

The breakage rate of the assemblage is relatively low as on average $65 \%$ of the bones are complete. The long bones of the limbs have the most notable breakage rates, at only $30 \%$ of complete bones on average. However, breakage tends to affect especially adult individuals (fig. 9). The girdles have a varying preservation since the scapulae are less well preserved than the coxal bones. All age groups included, small elements such as the ends of the legs (metacarpals, metatarsals and tarsals) are the best preserved in the assemblage. The cranial elements (maxilla and mandible) and the ribs are never complete. Although they are not represented here, the vertebrae are, for their part, well preserved despite their relative fragility. Most of the breakage of the assemblage 
was caused during the excavation and/or the packaging as nearly $90 \%$ of fractures are recent, mainly affecting the long bones of the limbs. Within layer 8 in Regourdou, the part of breakage on dry bones is limited (11\%), and no break on fresh bone or shaft cylinders has been noted.

In terms of the bone surfaces, they are very well preserved and do not seem to have suffered from climatic effects. Apart from a few anecdotal traces of dissolution and roots, it would appear that little biological and non-biological processes have affected the rabbit carcasses. Only a complete humerus has parallel grooves (fig. 10), perpendicular to the axis of the diaphysis, probably resulting from the action of a rodent (Brain 1981). Furthermore, the absence of evidence related to the intervention of a human or non-human predator should be noted.

Table 3 - Number of Identified Skeletal Parts (NISP, here NRD) and Minimum Number of Elements (MNE, here NME) of hares from level 4 at Regourdou.

\begin{tabular}{|c|c|c|c|}
\hline Anatomie & NRD & NME & NRD complet \\
\hline Pariétal & 2 & 2 & 0 \\
\hline Occipital & 3 & 2 & 0 \\
\hline Os pétreux & 6 & 5 & 5 \\
\hline Maxillaire & 4 & 2 & 0 \\
\hline Mandibules & 3 & 2 & 0 \\
\hline hcisives infërieures & 1 & 1 & 1 \\
\hline Dents jugales inférieures isolées & 4 & 4 & 4 \\
\hline ncisives supérieures & 1 & 1 & 1 \\
\hline Dents jugales superieures isolées & 2. & 2 & 2 \\
\hline Vertébres cervicales & 11 & 111 & 11 \\
\hline Vertèbres thoraciques & 8 & 8 & 7 \\
\hline Vertèbres lombaires & 29 & 29 & 27 \\
\hline Sacrum & 6 & 5 & 5 \\
\hline Vertébres caudales & 2 & 2 & 2 \\
\hline cotes & 39 & 26 & 1 \\
\hline Sternébres & & & \\
\hline Scapulä & 12 & $100^{-1}$ & $\dddot{0} 0$ \\
\hline Humérus & 13 & 10 & 5 \\
\hline Radius & 17 & 11 & 3 \\
\hline Una & 11 & 11 & 0 \\
\hline Carpiens & - & - & - \\
\hline Metacarpien I & - & - & - \\
\hline Métacarpien II & 5 & 5 & 4 \\
\hline Métacarpien III & 5 & 5 & 2 \\
\hline Metacarpien IV & 3 & 3 & 2 \\
\hline Metacarpien V & $\therefore$. & 1. & 1. \\
\hline coxal & 18 & 13 & 2 \\
\hline Fémur & 16 & 12 & 6 \\
\hline Patella & - & - & - \\
\hline Tibio-Fibula & 17 & 12 & 3 \\
\hline Calcanéus & 8 & 8 & 8 \\
\hline Talus & 1 & 1 & 1 \\
\hline Tarsiens & 1 & 1 & 1 \\
\hline Metatarsien II & 4 & 4 & 1 \\
\hline Métatarsien III & 7 & 7 & 3 \\
\hline Métatarsien N & 5 & 5 & 3 \\
\hline Métatarsien V & 8 & 8 & 7 \\
\hline Métapodes. & 5 & 5 & \\
\hline Phalange proximale & 13 & 13 & 13 \\
\hline Phalange mésiale & 1 & 1 & 1 \\
\hline Phalange distale & - & - & - \\
\hline Total & 292 & 248 & 132 \\
\hline
\end{tabular}


Table 4 - Degree of ossification of the extremities of hare long bones from level 4 at Regourdou.

\begin{tabular}{|ll|c|cc|c:c|}
\hline \multirow{2}{*}{} & & Âge de & \multicolumn{2}{|c|}{ Oss ifié } & \multicolumn{2}{c|}{ Non oss ifié } \\
& & l'ossification & $\mathbf{N}$ & NMI & $\mathbf{N}$ & NMI \\
\hline \multirow{2}{*}{ Humérus } & Proximal & 11 mois & 4 & 2 & 6 & 4 \\
& Distal & 4 mois & 7 & 5 & 0 & 0 \\
\hline \multirow{2}{*}{ Ulna } & Proximal & 4 mois & 11 & 7 & 0 & 0 \\
& Distal & - & - & - & - & - \\
\hline \multirow{2}{*}{ Radius } & Proximal & 4 mois & 10 & 5 & 1 & 1 \\
& Distal & 11 mois & 5 & 3 & 2 & 1 \\
\hline \multirow{2}{*}{ Fémur } & Proximal & 4 mois & 8 & 4 & 0 & 0 \\
& Distal & 11 mois & 6 & 3 & 6 & 3 \\
\hline \multirow{2}{*}{ Tibia } & Proximal & 11 mois & 4 & 2 & 7 & 4 \\
& Distal & 4 mois & 8 & 6 & 0 & 0 \\
\hline
\end{tabular}

Figure 5 - Skeletal element representation of hares from Regourdou level 4. NISP values are given above the bars.

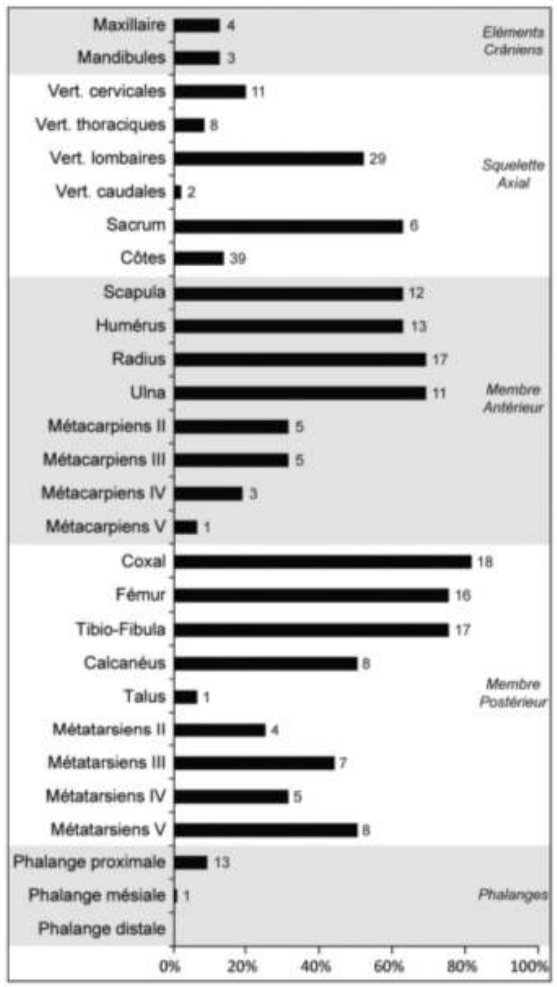


Figure 6 - Examples of microwear recovered on hare bones from Regourdou level 4. A: Traces of weathering on a right mandible; B: Traces of abrasion on a right radius.
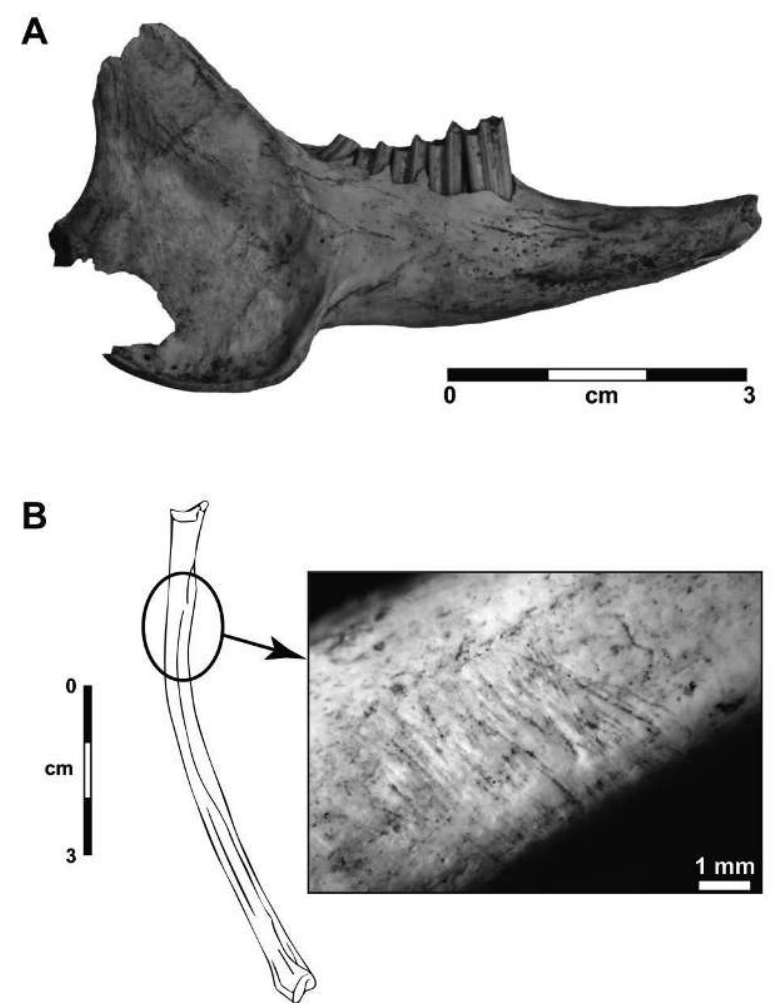

\section{4 - Body sizes of the leporidae}

The mountain hares of layers 8, 4, 3 and 2 of Regourdou have relatively different sizes (fig. 11). The individuals of layer 4 are small, while those of layer 8 are significantly larger (tab. 7). The individuals of layers 3 and 2 are intermediate in size with no statistical difference with those of layers 8 and 4, suggesting an evolution of the body size of the mountain hares within the Regourdou sequence. In terms of dental conformation, it is relatively difficult to distinguish the differences between the Pleistocene and modern populations (fig. 12). The morphology of the mountain hares' p3 from the studied sites appears relatively stable over time, although it is interesting to note that the individuals of layer 4 in Regourdou tend to differ from the variability of the other Pleistocene hares analysed.

About the rabbits, no significant difference exists between the individuals of layers 8 and 3. Their body sizes differ significantly from the modern populations and from the late Pleistocene ones; they fall within the body size values from the late Middle Pleistocene and the early Upper Pleistocene (fig. 11), either by using the measurements of the humerus and the calcaneus or by the analyses in 2D geometric morphometry (fig. 13). Indeed, on the basis of dental conformation, modern populations (crosses) and the late Upper Pleistocene ones (triangles) appear to differ from the variability of the Middle Pleistocene (circles) and of the early upper Pleistocene (squares) populations. This observation suggests that the Regourdou population fall within the variability of the latter. 


\section{4 - Discussion}

\section{1 - Origin of the accumulation of the layer 4 mountain hares}

30 Following these analyses, several taphonomic characteristics could be noted. The mortality profile highlights that the mountain hare accumulation of layer 4 at Regourdou is mainly consisting of sub-adult individuals. This assemblage is very well preserved, as few bones have undergone the action of abiotic and biological processes. The distortions seen on the bone representation are not from differential conservation process. The skeleton is relatively well represented suggesting the introduction of whole individuals within the cave. The assemblage is little fragmented (58\% of complete bones), especially as nearly $60 \%$ of the breaks have been generated recently (since and/or during the excavation). No trace of predation was observed, and only some traces evidenced the action of sediment transport and runoff, as well as possibly a marginal scavenging carried out by a small carnivore. All these observations tend to suggest a natural accumulation of these mountain hares without predation events at Regourdou.

31 Similar accumulations of mountain hares have been found previously in a karstic environment, in natural deposits as at Coulet des Roches in the Vaucluse region (pers. obs., MP), at Igue du Gral (J.-B. Mallye, pers. comm.) and Coudoulous II (Cochard 2004a) in the Lot region and Igue des Rameaux in the Tarn-et-Garonne region (Cochard 2004a). Taphonomic studies of these assemblages of Lepus timidus are characterized by a predominance of sub-adult individuals, like in Regourdou. Regarding the sites of Coudoulous 2 and Igue des Rameaux, D. Cochard (2004a) suggests a "natural primary accumulation" of mountain hare remains without predator intervention, probably a result of an accidental fall into the cave. The skeletal profile observed for the Regourdou hares reflects similar tendencies to those of these two sites (fig. 14). Breakage is also relatively close between Regourdou and these two sites, with similar percentages of complete bones (58\% in Regourdou against 61\% Coudoulous II and 65\% at Igue des Rameaux). But we believe it was lower in Regourdou since $59 \%$ of the breaks have been made recently. If we dismiss this very high recent break parameter, it results that the fractures occurred mainly on dry bones like in the other two comparative sites, certainly implying post-depositional changes to complete elements at the time of their deposit within the cavity. Finally, no evidence allows attributing to a predator the primary accumulation of mountain hare in Regourdou. Suspected carnivore traces on two remains, like in eight elements of Coudoulous II (Cochard 2004a) could result from a secondary modification of the assemblage.

32 All the evidence observed on the Regourdou mountain hares advocate a natural accumulation of accidental type probably following a fall in the context of a pitfall-trap, as has been suggested in the other South-western France karst formations mentioned above. Therefore this hypothesis seems most likely in Regourdou, especially since it has been assumed that the cave has functioned as a pitfall-trap to explain the presence of large herbivores at the site during the MIS 4 (Cavanhié 2010). 


\section{2 - Origin of the rabbit accumulation of layer 8} with almost identical proportions in the numbers of juveniles (11), sub-adults (12) and adults (10). The carcasses were introduced whole in the site and have a relatively homogeneous conservation of the different anatomical parts. The elements of the anterior and posterior limbs are relatively well represented as well as the cranial elements and lumbar vertebrae. Small elements such as phalanges and some tarsal bones (navicular, cuboid) are in turn underrepresented. Although the impact of a differential conservation cannot be totally ruled out, it seems that it is not the major factor of the specific aspects of this bone representation, as the loss of elements, especially small ones, may have occurred during excavation and/or sieving (Val and Mallye 2011). Overall, the bones have suffered little from breakage (65\% are whole bones), and in this case the breaks are mainly recent (89\%). Thus, at the time of the excavation, the skeletal elements must have been, for nearly all of them, whole. Moreover, few processes have modified and altered the bone surfaces. Only some anecdotal traces of dissolution, roots and rodent teeth (one remain) were identified. Consequently, none of these evidence argues in favour of an intervention of predators in the rabbit accumulation of layer 8 . only burrowing leporid. In his synthesis about intrusive contributions in archaeological sites, D. Cochard (2007) emphasizes that a natural mortality of attritional type for rabbits can be characterized by:

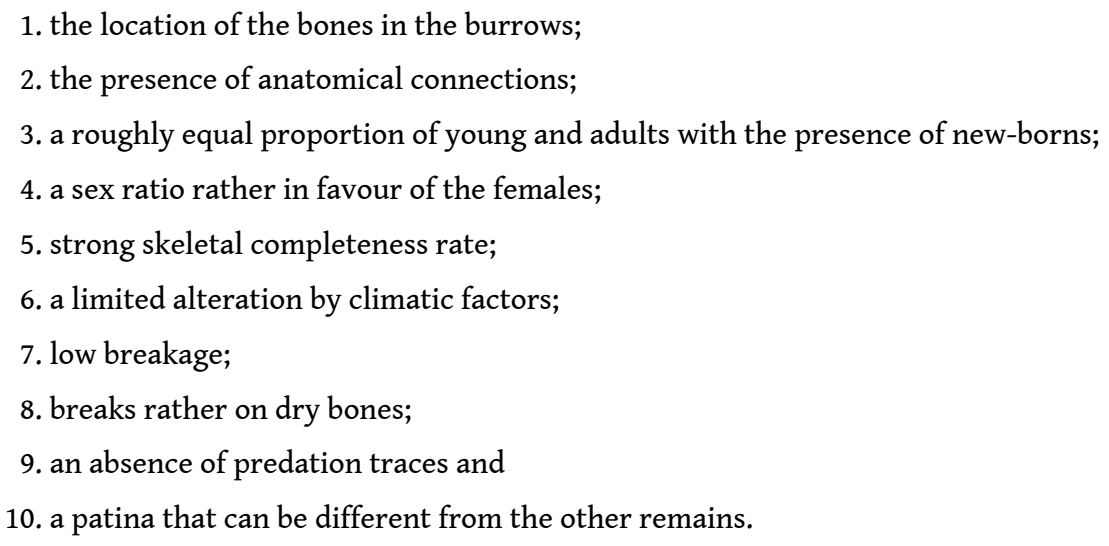

The accumulation of rabbits in layer 8 shows many similarities. The carcasses, introduced whole in the assemblage, are relatively complete; they show a very low ancient breakage rate (in situ) and are little altered by abiotic and biological agents. Moreover, it has been recently reported to us that rabbit skeletons were found in anatomical connection in their burrows during the excavation (E. Bonifay, pers. comm.).

Despite the current lack of detailed references on natural mortality of attritional type, the evidence collected on the Regourdou material plead for the hypothesis of such an accumulation. Although this argument is often used to explain the presence of these animals in the archaeological deposits (Cochard 2004a), this is the first time it is highlighted in a karstic context for the Pleistocene. 
Table 5 - Number of Identified Skeletal Parts (NISP, here NRD) and Minimum Number of Elements (MNE, here NME) of rabbits from level 8 at Regourdou.

\begin{tabular}{|c|c|c|}
\hline Anatomie & NNO & NQAE \\
\hline Fragnents craniens & 125 & \\
\hline Os petteux & 41 & 34 \\
\hline Mexilare & 72 & 38 \\
\hline Mandbules & 59 & 36 \\
\hline hesives intereures & 58 & 55 \\
\hline Dents jugales interieures mpi/sol & 202 & 202 \\
\hline neisives 1 et 2 superieures & 72 & 72 \\
\hline Dents jugales superieurs inplisol. & 196 & 196 \\
\hline Vertecres cervicales & in & 60 \\
\hline Vertebres thoraciques & 110 & 97 \\
\hline Ventecres lontaries & 165 & 144 \\
\hline Ventebres inder. & 49 & . \\
\hline saccum & 23 & 22 \\
\hline Vertebres caudales & 36 & 29 \\
\hline Chtes & 144 & 48 \\
\hline Stemetres. & 18 & \\
\hline scapuia & 40 & $\dddot{3} \theta$ \\
\hline Humeress & 66 & 55 \\
\hline Pasars & 57 & 37 \\
\hline una & 51 & 49 \\
\hline Cappiens & . & - \\
\hline Mtacarpien 1 & . & . \\
\hline Metacarpien II & 29 & 29 \\
\hline Metacarpien II & 32 & 32 \\
\hline Metacarpien N & 25 & 25 \\
\hline Metacarpien V & 13 & 13 \\
\hline Metacappien nd. & 7 & \\
\hline Coxal & 73 & $5 i$ \\
\hline Fomer & $\pi$ & 60 \\
\hline Patela & 2 & 2 \\
\hline Toi-Fituta & 58 & 38 \\
\hline Cakanous & 62 & 61 \\
\hline Taus & 39 & 39 \\
\hline Neviculare & 12 & 12 \\
\hline Cubovio & 6 & 6 \\
\hline Guneforme & 1 & 1 \\
\hline metatarsien I & 38 & 36 \\
\hline Metatarsien II & 36 & 36 \\
\hline Metatarsien $N$ & 40 & 40 \\
\hline Metatarsien V & 44 & 44 \\
\hline Metatsaiennd & 9 & \\
\hline Phalange proximale & 185 & 165 \\
\hline Phalange mestiale & 64 & 64 \\
\hline Phalange distale & 41 & 41 \\
\hline
\end{tabular}

Table 6 - Degree of ossification of the extremities of rabbit long bones from level 8 at Regourdou.

\begin{tabular}{|c|c|c|c|c|c|c|c|c|}
\hline & \multirow{2}{*}{$\begin{array}{c}\text { Áge de } \\
\text { rossification }\end{array}$} & \multicolumn{3}{|c|}{ Ossifie } & \multicolumn{3}{|c|}{ Non ossifie } \\
\hline & & & $N$ & & NMI & $\mathbf{N}$ & & NMI \\
\hline \multirow{2}{*}{ Hurnerus } & Proximal & 9 mos & 14 & ? & 0 & 26 & ; & 15 \\
\hline & Distal & 3 mois & 29 & 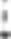 & 16 & 26 & i & 11 \\
\hline \multirow{2}{*}{ Una } & Proximal & $4 \mathrm{mos}$ & 26 & ; & 14 & 25 & i & 16 \\
\hline & Distal & 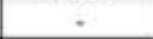 & - & : &. & - & 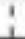 & $\therefore$ \\
\hline \multirow{2}{*}{ Radius } & Aroximal & 3 mois & 29 & ? & 17 & 8 & : & 5 \\
\hline & Distai & 9 mos & 16 & i & 9 & 16 & 1 & 12 \\
\hline \multirow{2}{*}{ Femur } & Aroximal & $5 \mathrm{mos}$ & 24 & 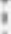 & 12 & 15 & I & 8 \\
\hline & Distaf & 9 mois & 19 & i & 10 & 41 & i & 17 \\
\hline \multirow{2}{*}{ Tbia } & Proximal & 10 moss & 12 & & 7 & 18 & s & 6 \\
\hline & Distal & $5 \mathrm{mos}$ & 17 & & 10 & 21 & 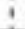 & 11 \\
\hline
\end{tabular}


Figure 7 - Skeletal element representation of complete rabbit bones from Regourdou level 8. NISP values are given above the bars.

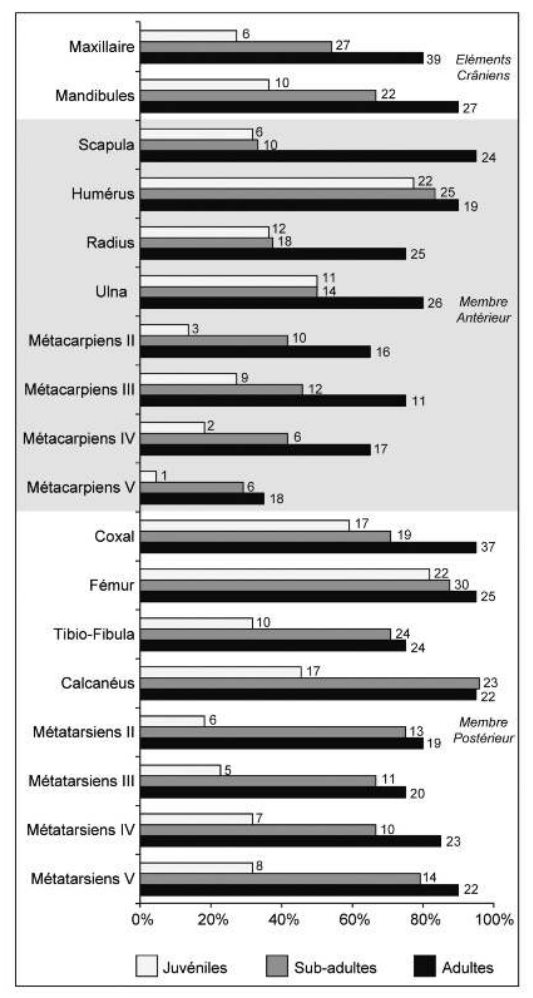

\section{3 - Hare and rabbit: two different stories}

This study conducted on both leporids, the mountain hare and the rabbit, from layers 4 and 8 in Regourdou suggests two different stories about their accumulations. Concerning the mountain hares, their presence would result from accidental falls of individuals in a natural shaft in the karst, simultaneously with the setting up of this layer in the MIS 5 (fig. 15A). This hypothesis of a pitfall-trap type of configuration in Regourdou agrees with the observations on the large herbivore fauna (Cavanhié 2010) and with E. Bonifay's interpretations (Bonifay 1964, 1965, 2002). As for the rabbits of layer 8 , the evidence also argue for a natural mortality, but in this case of the attritional type.

Although it was not possible to carry out a taphonomic study on the rabbits in layer 3 , probably due to the selective sorting operated during the excavation, we can emphasize that these bones have the same surface state and the same patina as the individuals from layer 8. In addition, no difference in body size (see fig. 11) or dental conformation (see fig. 13) were identified between layers 8 and 3. Both assemblages have many similarities and appear homogenous, which could suggest they are issued from one single "event." The existence of rabbit burrows within the cave, recognized during the excavations (E. Bonifay, pers. comm.), now raises questions about the importance of the "bioturbations" within this site. All these observations allow us to propose the hypothesis that all the rabbits from layers 8 and 3 could belong to a single population (and probably those of other layers as well). According to this hypothesis, rabbits, constrained by very severe weather conditions, might have found refuge in the 
cave to establish their burrows through the various layers of the site when the mouth of Regourdou was filled, probably contributing to disturb others remains (fig. 15B).

\section{4 - Biochronolology and climatic significance of Regourdou leporids}

Since the Middle Pleistocene, rabbits and hares show diachronically similar variations in body size that could be directly related to the local climate changes (see fig. 11). The rabbits' body size gradually increased during the Middle Pleistocene with very large individuals as in Combe-Grenal and Pech de Aze 2, and then decreased from the beginning of the Upper Pleistocene (Gavaudun and Coudoulous 1) until the end of this period in which individuals had reduced sizes (Abri du Morin, Gare de Couze, Igue du Gral and Pont d'Ambon). Similarly, the mountain hares have small sizes in the Middle Pleistocene like in Camp de Peyre (MIS 11-12) and La Fage (MIS 10). Their sizes increased gradually (Igue des Rameaux; MIS 9-10). Thereafter, the body size of the mountain hares tended to diminish during the Upper Pleistocene, becoming smaller at the end of the Ice Age as in La Madeleine or Igue du Gral. Considering the observations conducted on the current populations (Davis and Moreno-Garcia 2007), it is likely that the body size of leporid populations of the Pleistocene in southern France increased mainly during cold periods and decreased during more temperate phases.

Figure 8 - Skeletal element representation of partial rabbit bones from Regourdou level 8.

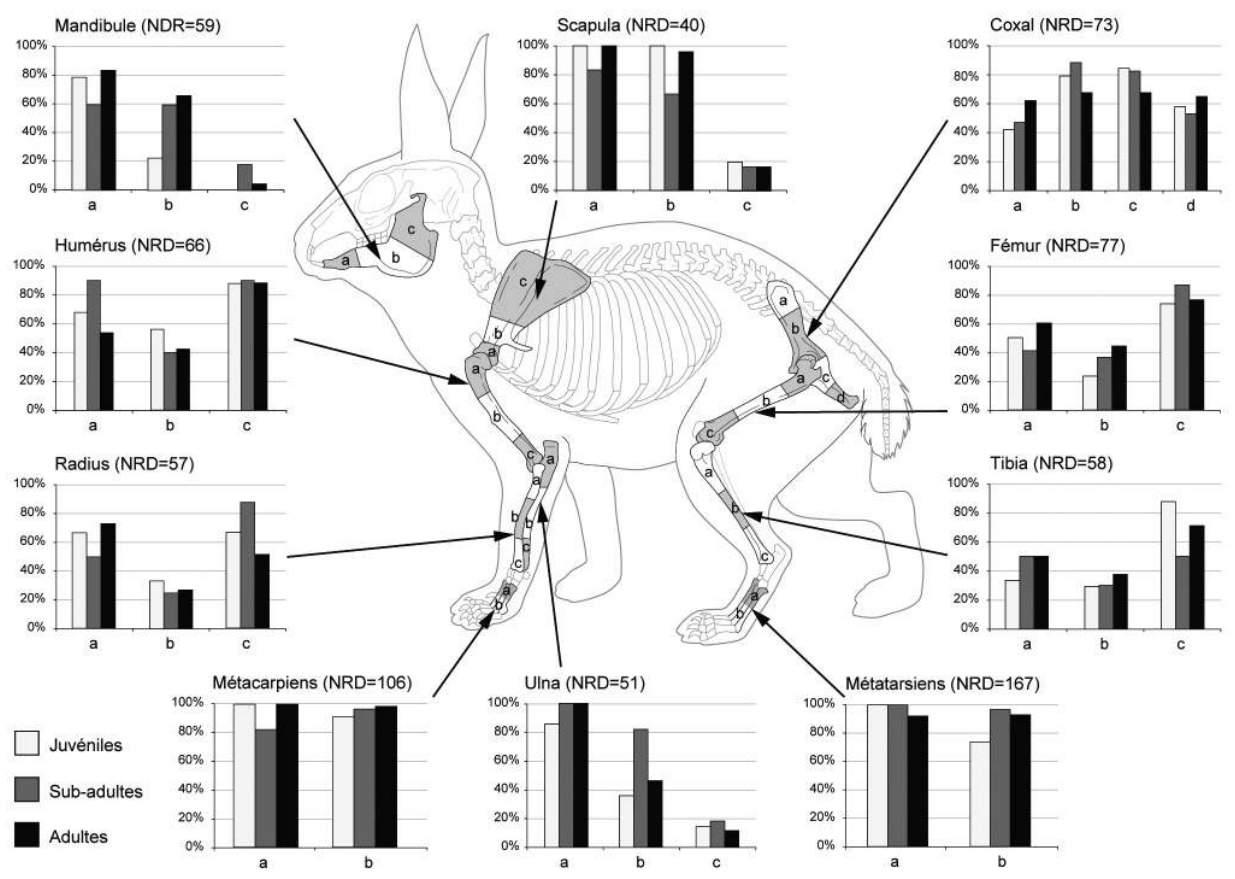


Table 7 - Wilcoxon significance tests between the different levels at Regourdou. Differences of $p<$ 0.05 are considered statistically significant.

\begin{tabular}{|l|c|c|c|c|}
\cline { 2 - 3 } \multicolumn{1}{c|}{} & couche 8 & couche 4 & couche 3 & couche 2 \\
\hline couche 8 & \multicolumn{2}{c}{} \\
\hline couche 4 & $\mathbf{0 , 0 2 2 5}$ & \multicolumn{1}{c}{} \\
\hline couche 3 & 0,0663 & 0,0947 & \multicolumn{1}{c}{} \\
\hline couche 2 & 0,1807 & 0,1932 & 0,6806 & \multicolumn{1}{c}{} \\
\hline
\end{tabular}

Figure 9 - Skeletal element representation of complete rabbit bones from Regourdou level 8. NISP values are given above the bars.

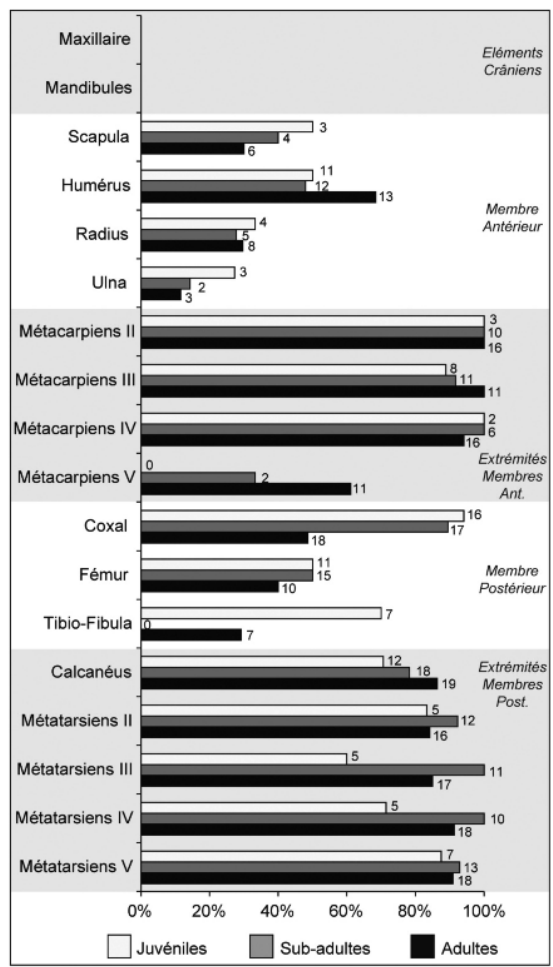



8.

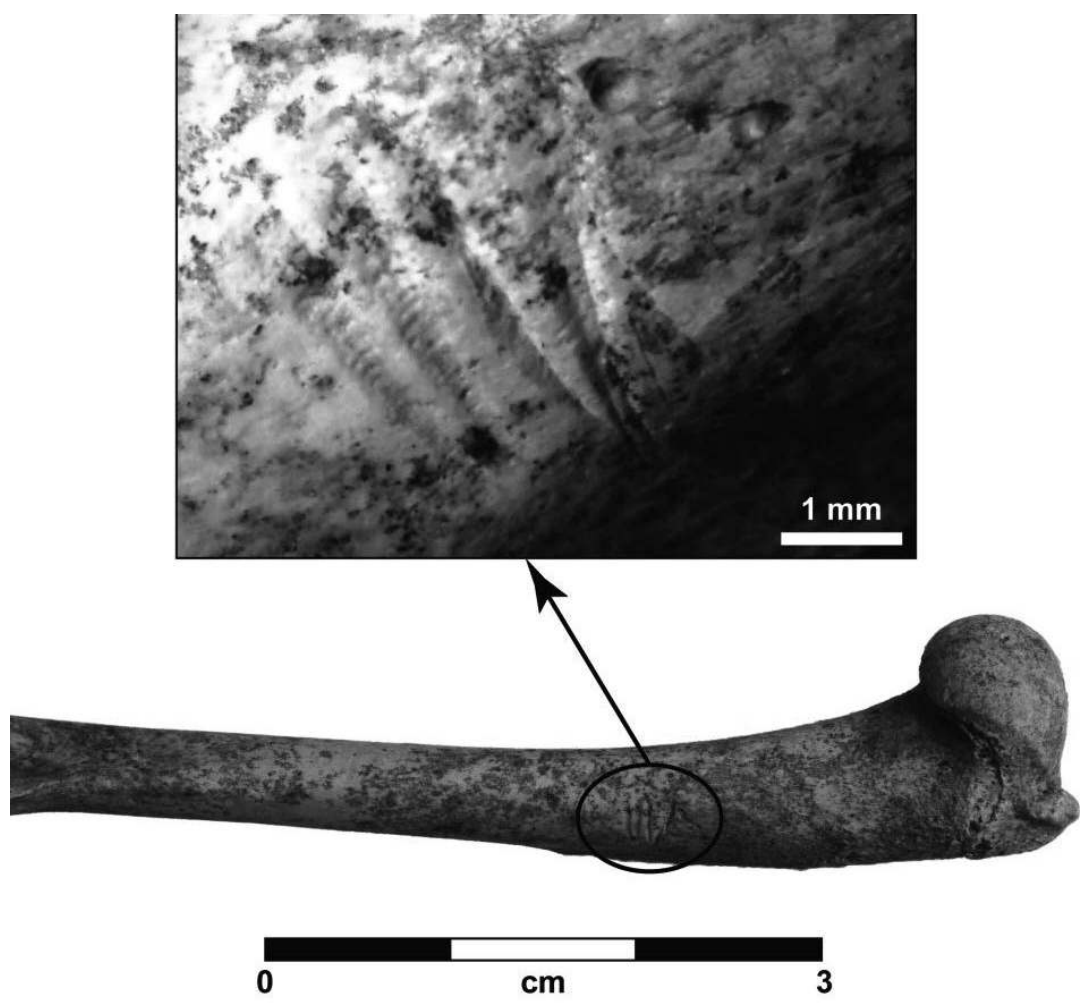

If no major morphological differences were observed in mountain hares between layers 2, 3 and 8, however, it appears that the dental conformation of individuals of layer 4 tends to differentiate them from the known variability in the Pleistocene and modern populations. In addition, these hares from layer 4 also tend to differ from those of layers 8,3 and 2, by their smaller sizes. Therefore, the large size of the mountain hares of layer 8 would reflect a fairly rigorous environment, which is consistent with observations carried out on the micro fauna and especially the presence of the steppe pika (0. pusilla). These criteria could be consistent with an affiliation to this hare population around the beginning of the Upper Pleistocene. As the body size of the individuals in layers 3 and 2 increases with regard to layer 4, this observation may reflect a cooling of the climate, as also shown by the presence of the steppe lemming (Lagurus Lagurus) in layer 3 and the significant increase of the number of remains of reindeer in layer 2. According to Bonifay, layer 2 would reflect the isotope stage 4, which appears to be consistent with measurements taken on the postcranial skeleton (fig. 11). On the opposite, the mountain hares of layer 4 being clearly smaller, they could reflect a warmer environment, which is consistent with the faunal associations of large and small mammals of this layer, with a temperate tendency.

To our knowledge, the presence of mountain hare has never been described in a temperate Pleistocene environment. Its current distribution is limited to higher latitudes and altitudes, its presence in the deposits is often used to reconstruct "cold climate conditions" (Donard 1982). Now, this current distribution is not a simple climate consequence and also appears to result from inter-specific competition, especially with the European hare (L. europaeus). Indeed, the introduction by humans of European hares in southern Sweden inhabited by mountain hares, brought to light the existence of a strong interspecific competition between the two species, with the 
distribution of the mountain hare having been pushed back towards the highest latitudes (Thulin 2003). Recent genetic studies of the modern European hare showed that it would not have reached Western Europe before the end of the Upper Pleistocene or the early Holocene (Fickel et al. 2008; Stamatis et al. 2009). This recent colonization of the European hare in France, and more generally in northern Europe at the end of the Ice Age could then have helped to push back the hares towards higher latitudes and altitudes (López-Martínez 1980; Veitschegger, Fladerer, Nagel 2015). As emphasized by N. López-Martínez (1980 - p.15), "in the absence of its competitor Lepus europaeus, Lepus timidus can live in lowlands with mild climate (e.g. Ireland); therefore it is not a species adapted to a cold climate, but rather, it is a species that took refuge in northern habitats, islands and in altitude, forced by the pressure of its competitor, who cannot reach these habitats. It is therefore important not to try to draw climate conclusions based on the mere presence of $\mathrm{L}$. timidus, unless by proving the synchronic existence of $\mathrm{L}$. europaeus, which is not yet the case." The presence of the mountain hare in the environment of Regourdou during the last interglacial is therefore plausible, especially as, to our knowledge, no MIS 5e site with specifically determined hare remains (European or mountain) is known.

As for rabbits, no morphological or metric differences were found between the individuals of layer 8 and those of layer 3, highlighting large individuals, suggesting a cold climate period. Moreover, the taphonomic analysis allowed us to hypothesize a natural accumulation of attritional type and would tend to show that this is a single and same population that came to settle at the site at the end of the sedimentary filling. Nevertheless, these individuals do not fall into the population variability of the late Upper Pleistocene nor of modern populations. At the dental conformation level, the Regourdou rabbits also tend to differ from individuals of these periods, especially at the paraflexid (see fig 4A; Pelletier et al. 2015). In terms of size, the Regourdou rabbits are relatively close to Combe-Grenal and Gavaudun, these two sites being related to the MIS 6. However, as the Regourdou rabbits cannot be related to the MIS 6 (see attritional mortality), we can assume that their presence in the environment of Regourdou is contemporary with the cold and dry climate conditions of the MIS 4, the only layer corresponding to this period being layer 2, or subsequently to its built up, in the MIS 3 . 
Figure 11 - Mean and range of variation of transverse diameter (DT) of the distal epiphysis of a humerus (on the left), and of total length ( $L$ tot) of the calcaneus (on the right). The measurements were taken only on adult specimens. The bars represent the minimum and maximum values for each series ; the squares represent hares and the circles represent rabbits. *following Donard 1982; ** Personal data.

DT distal humérus $(\mathrm{mm})$

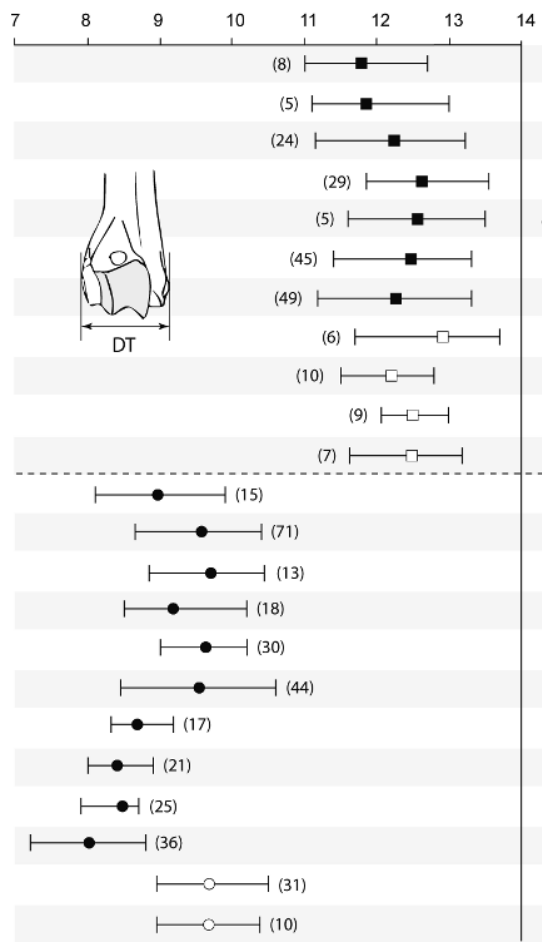

$\mathrm{L}$ tot calcanéus $(\mathrm{mm})$

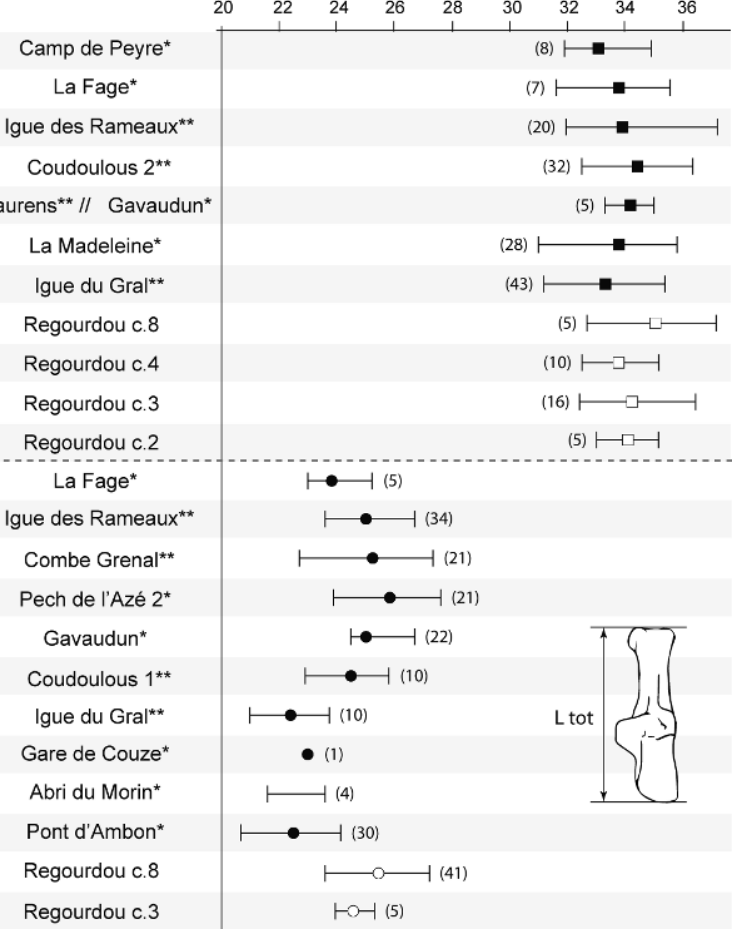

Figure 12 - Principal Components Analysis (ACP) based on nine landmarks taken on the $\mathrm{p} 3$ of the hare samples. The first and second axes together represent $37.74 \%$ of the total variation.

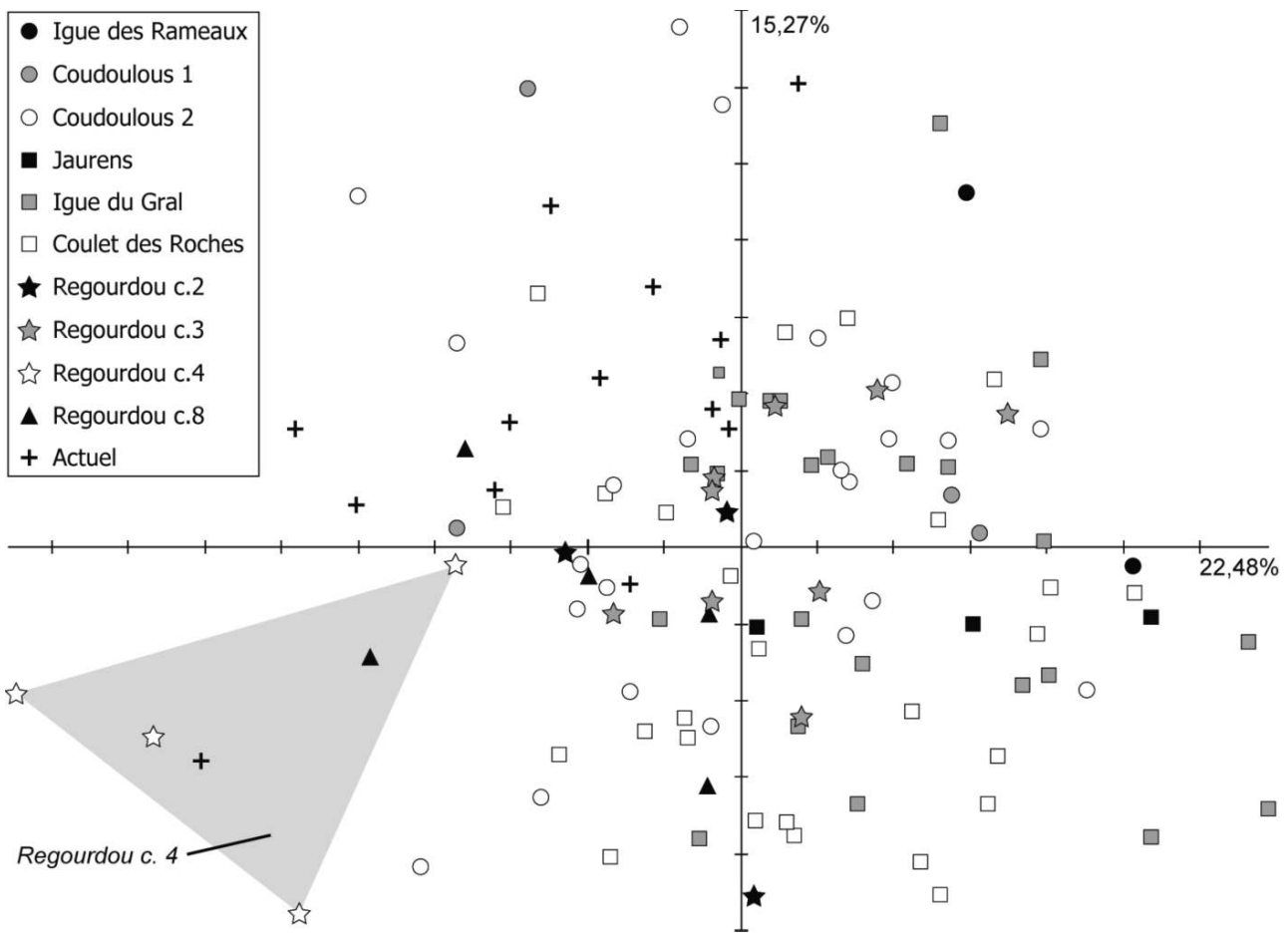


Figure 13 - Principal Components Analysis (ACP) based on nine landmarks taken on the p3 of the rabbit samples. The first and second axes together represent $42.87 \%$ of the total variation.

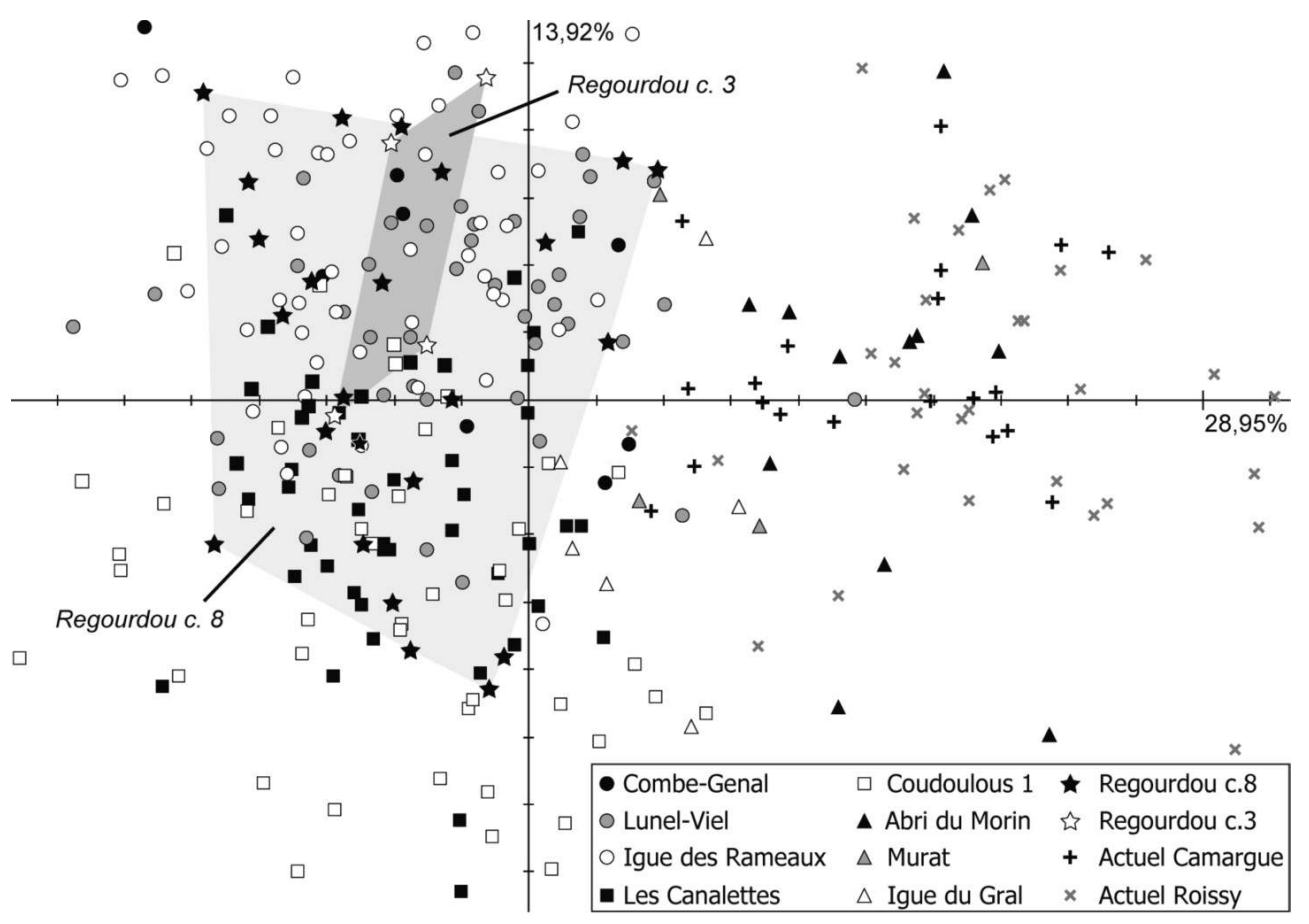

Figure 14 - Comparison between skeletal element preservation of hares from Regourdou level 4 with those from level 4 at Coudoulous 2 and level 30 at l'Igue des Rameaux (data from Cochard 2004a).

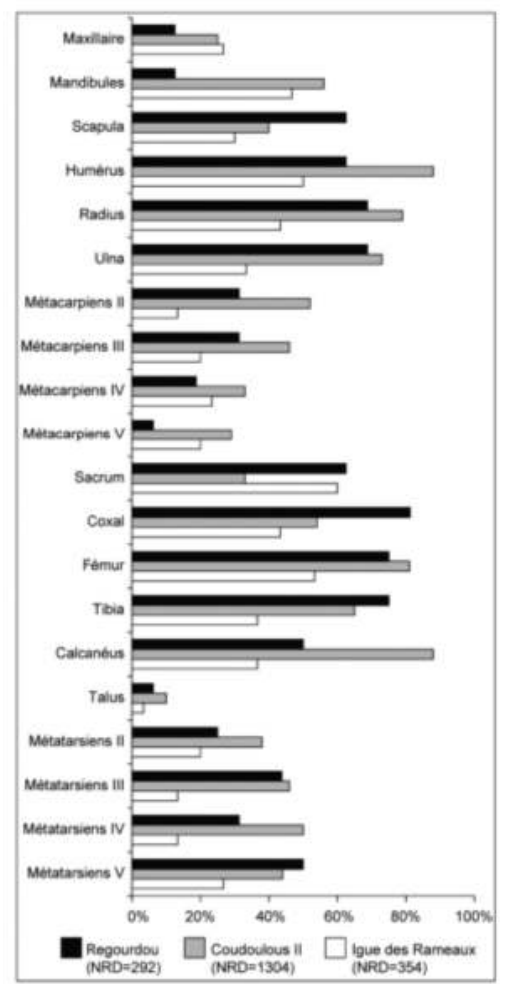


Figure 15 - Proposed hypotheses for the accumulation of hares (A) and rabbits (B) in level 4 at Regourdou.

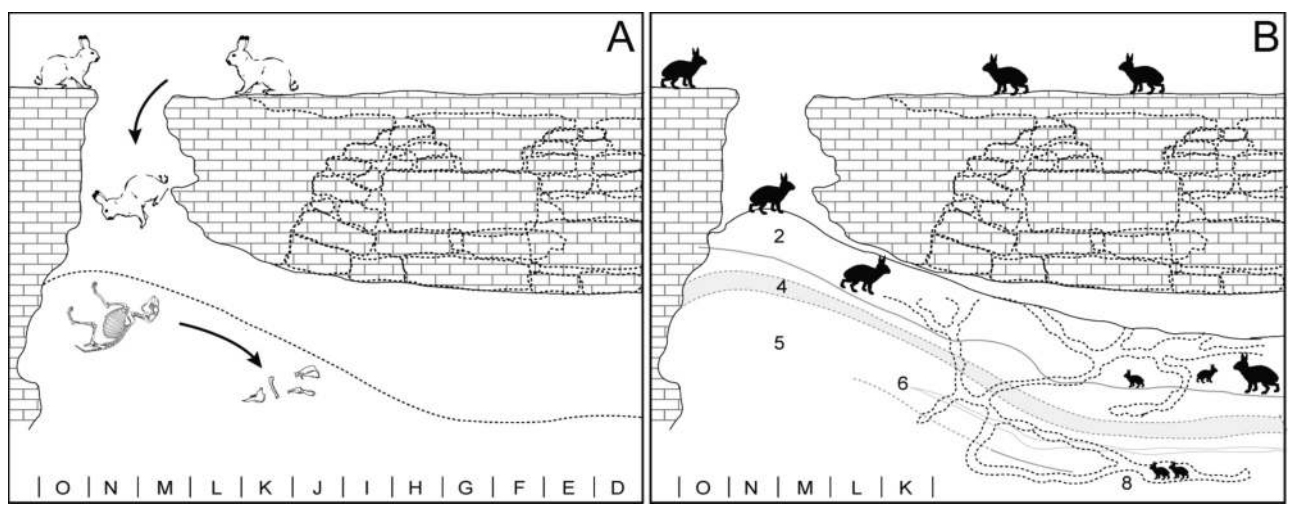

\section{5 - Conclusions}

The site of Regourdou was particularly affected by very complex sedimentological, historical and taphonomic contexts. Therefore, it seems very important to us to initiate a discussion about the abundance of leporid remains, and especially to highlight a tendency about the origin of their accumulation. Our work shows the importance of the taphonomic and paleontological studies carried out on such a deposit.

Indeed, it has been possible to highlight two types of natural accumulations within the filling of Regourdou: attritional or accidental. This result is up to date unique for an Upper Pleistocene site. The constitution of modern reference sources on these types of accumulations, coupled with the resumption of excavations at Regourdou and new absolute dating, should validate these hypotheses.

Our research also shows the interest of coupled studies in palaeontology and in taphonomy when numerous information are lacking for a site. This allowed us to better understand the chronological history of the Regourdou site, which keeps a major interest in the characterization of the Neandertals' environment during the Early Middle Palaeolithic.

\section{BIBLIOGRAPHY}

Alhaique F. 1994 - Taphonomic analysis of the faunal remains from the "P" and "M" layers of the Arene Candide (Savona, Italy). Quaternaria Nova, 4, p. 263-295.

Angerbjörn A. et FLUX J.E.C. 1995 - Lepus timidus. Mammalian Species, 495, p. 1-11.

Biadi F. et Le Gall A. 1993 - Le lapin de garenne. Vie Gestion et chasse d'un gibier authentique. Paris: Office national de la chasse Hatier, $160 \mathrm{p}$.

Binford L.R. 1981 - Bones: Ancient Men and Modern Myths. New-York: Academic Press, 320 p. 
Blasco R. et Fernández Peris J. 2012 - A uniquely broad spectrum diet during the Middle Pleistocene at Bolomor Cave (Valencia, Spain). Quaternary International, 252, p. 16-31.

BONIFAY E. 1964 - La grotte de Régourdou (Montignac, Dordogne). Stratigraphie et industrie lithique moustérienne. L'Anthropologie, 68, p. 49-64.

Bonifay E. 1965 - Un ensemble rituel moustérien à la grotte du Régourdou (Montignac, Dordogne). In : Actes du VIème Congrès International des Sciences Préhistoriques et Protohistoriques, Session I-IV. Rome, p. 136-140.

Bonifay M.-F. 1989 - Analyse taphonomique des Ursidés de la grotte sépulcrale néandertalienne du Régourdou (dordogne, france). in : $\mathrm{m}$. otte (ed.), l'homme de néandertal. colloque international de liège (1986). liège, eraul, p. 45-47.

Bonifay E. 2002 - L'Homme de Néandertal et l'ours (Ursus arctos) dans la grotte du Régourdou (Montignac-sur-Vézère, Dordogne, France). In : T. Tillet, L.R. Binford (Ed.), L'Ours et l'Homme. Actes du Colloque d'Auberivesen-Royans (1997). Liège, ERAUL, p. 247-254.

Bonifay E., Vandermeersch B., Couture C. et Panattoni R. 2007 - La sépulture néandertalienne du Régourdou (Montignac-sur-Vezère, Dordogne). Mercuès : Documents du Centre d'Etude et de Recherche sur les Lacs, Anciens lacs et Tourbières du Massif-Central, 18 p.

Bookstein F.L. 1991 - Morphometric tools for landmark data: Geometry and Biology. New York: Cambridge University Press, $435 \mathrm{p}$.

Brain C.K. 1981 - The Hunters or the Hunted? An introduction to African Cave Taphonomy. Chicago : University of Chicago Press, 365 p.

Brugal J.-P. 2006 - Petit gibier et fonction de sites au Paléolithique supérieur. Paleo, 18, p. 45-68.

BRUGAL J.-P. et JAUBERT J. 2006 - A long Palaeolithic sequence in Southwest France: the karstic sites of Coudoulous (Lot, Quercy, France). Document présenté à la Société de Paléoanthropologie, 24 -26 Avril, 2006, San Juan, Puerto Rico.

Callou C. 2003 - De la garenne au clapier : étude archéozoologique du lapin en Europe occidentale. Paris Publications scientifiques du Muséum, 19, 358 p.

CASTEL J.-C., COUMONT M.-P., BRUGAL J.-Ph., LAROULANDIE V., CAMUS H., CHAUVIÈRE F.-X., COCHARD D., GUADELLI J.-L., KUNTZ D., MARTIN H. et MOURRE V. 2008. La fin du Paléolithique supérieur en Quercy : l'apport de l'Igue du Gral (Sauliac-sur-Célé, Lot). In : J. Jaubert, I. Ortega, JG. Bordes (Ed.), Les sociétés du Paléolithique dans un Grand Sud-Ouest de la France : nouveaux gisements, nouveaux résultats, nouvelles méthodes. Société Préhistorique Française, 47, p. 335-353.

Cavanhié N. 2010 - L'ours qui a vu l'homme ? Étude archéozoologique et taphonomique du site paléolithique moyen de Regourdou (Montignac, Dordogne, France). Paleo, 21, p. 39-63.

Cochard D. 2004a - Les léporidés dans la subsistance paléolithique du sud de la France. Talence : Université Bordeaux I, 2004. 354 p. Thèse de doctorat.

Cochard D. 2004b - Etude taphonomique des léporidés d'une tanière de renard actuelle : apport d'un référentiel à la reconnaissance des accumulations anthropiques. Revue de Paléobiologie, 23, p. 659-673.

Cochard D. 2004c - Influence de l'âge des proies sur les caractéristiques des accumulations de léporidés produites par le hibou grand-duc. In : J.-P. Brugal, J. Desse (Ed.), Petits animaux et Sociétés humaines. Du complément alimentaire aux ressources utilitaires. XXIVe Rencontres Internationales d'Archéologie et d'Histoire d'Antibes. Antibes, APDCA, p. 313-316. 
Cochard D. 2007 - Caractérisation des apports de Léporidés dans les sites paléolithiques et application méthodologique à la couche VIII de la grotte Vaufrey. In : J. Evin (Ed.), Un siècle de construction du discours scientifique en Préhistoire. Actes du Congrès du Centenaire de la Société Préhistorique Française : un siècle de construction du discours scientifique en Préhistoire (Avignon, 20 au 24 septembre 2004). Mémoire de la Société Préhistorique Française, 3, p. 467-480.

Cochard D. 2008 - Discussion sur la variabilité intraréférentiel d'accumulations osseuses de petits prédateurs. Annales de Paléontologie, 94, p. 89-101.

Cochard D., Brugal J.-P., Morin E. et Meignen L. 2012 - Evidence of small fast game exploitation in the Middle Paleolithic of Les Canelettes, Aveyron, France. Quaternary International, 264, p. 32-51.

COUMONT M.-P. 2006 - Taphonomie préhistorique : Mammiferes fossiles en contexte naturel, les avenspièges, apport pour l'étude des archéofaunes. Aix-en-Provence : Université Aix-Marseille I, 2006. $513 \mathrm{p}$. Thèse de doctorat.

Crégut-Bonnoure E., Argant J., Bailon S., Boulbes N., Bouville C., Buisson-Catil J., Debard E., Desclaux E., Fietzke J., Fourvel J.-B., Frèrebeau N., Kuntz D., Krzepkowska J., Laudet F., Lachenal T., Lateur N., Manzano A., Marciszakm A., Margarit X., Mourer-Chauviré C., Oppliger J., Roger T., Teacher AG.F. et Thinon M. 2014 - The karst of the Vaucluse, an exceptional record for the Last Glacial Maximum (LGM) and the Late-glacial period palaeoenvironment of southeastern France. Quaternary International, 339-340, p. 41-61.

Cruz-Uribe K. et Klein R.G. 1998 - Hyrax and Hare Bones from Modern South African Eagle Roosts and the Detection of Eagle Involvement in Fossil Bone Assemblages. Journal of Archaeological Science, 25, p. 135-147.

Davis S.J.M. et Moreno-García M. 2007 - Of metapodials, measurements and music - eight years of miscellaneous zooarchaeological discoveries at the IPA, Lisbon. O Arqueólogo Português, Série IV, 25, p. 9-165.

Defleur A., Bez J.-F., Cregut-Bonnoure E., Desclaux E., Onoratini G., Radulescu C., Thinon M. et Vilette P. 1994 - Le niveau moustérien de la grotte de l'Adaouste (Jouques, Bouches-du-Rhône) : approche culturelle et paléoenvironnements. Bulletin du Musée d'anthropologie préhistorique de Monaco, 37, p. 11-48.

Delibes M. et Hiraldo F. 1981 - The rabbit as a prey in the Iberian Mediterranean ecosystem. In: K. Myers, C.D. MacInnes (Ed.), Proceedings of the World Lagomorph Conference. Guelph : University of Guelph, p. 614-622.

Delpech F. 1996 - L'environnement animal des Moustériens Quina du Périgord. Paleo, 8, p. 31-46.

DELPECH F. et PRAT F. 1995. Nouvelles observations sur les faunes acheuléennes de CombeGrenal (Domme, Dordogne). Paleo, 7, p. 123-137.

Desclaux E. 1992 - Les petits vertébrés de la Caune de l'Arago (Tautavel, Pyrénées-orientales): paléontologie, paléoécologie, taphonomie. Paris : Museum national d'histoire naturelle, 1992. 444 p. Thèse de doctorat.

Donard E. 1982 - Recherches sur les Léporinés quaternaires (Pléistocène moyen et supérieur, Holocène). Talence : Université Bordeaux 1, 1982. 191 p. Thèse de doctorat.

El Guennouni K. 2001 - Les lapins du Pléistocène moyen et supérieur de quelques sites préhistoriques de l'Europe méditerranéenne: Terra-Amata, Orgnac 3, Baume Bonne, la grotte du Lazaret, la grotte du Boquete de Zafarraya, Arma delle Manie. Étude paléontologique, achéozoologique et taphonomique. Parishèse de doctorat. 
Fickel J., Hauffe H.C., Pecchioli E., Soriguer R., Vapa L. et Pitra C. 2008 - Cladogenesis of the European brown hare (Lepus europaeus Pallas, 1778). European Journal of Wildlife Research, 54, p. 495-510.

Fontana L. et Chauvière F.-X. 2007 - L'exploitation du Lièvre variable à La Madeleine (Dordogne, France) et le statut d'un petit gibier au Dryas ancien. Paleo, 19, p. 303-336.

FoSSE P. 1994 - Taphonomie paléolithique : Les grands mammifêres de Soleilhac (Haute-Loire) et de LunelViel 1 (Hérault). Aix-Marseille I : Université de Provence, 1994. 257 p. Thèse de doctorat.

Gerber J.-P. 1973 - La Faune de grands mammifêres du Würm ancien dans le Sud-Est de la France. Université de Provence, 1973. 310 p. Thèse de doctorat.

GUÉRIN C., PHILIPPE M. et VILAIN R. 1979 - Le gisement pléistocène supérieur de la Grotte de Jaurens à Nespouls, Corrèze, France, Historique et généralités. Nouvelles Archives du Musée d'Histoire Naturelle de Lyon, 17, p. 11-16.

Hardy B.L., Moncel M.-H., Daujeard C., Fernandez P., Béarez P., Desclaux E., Chacon-Navarro M.G., Puaud S. et Gallotti R. 2013 - Imposible Neanderthals ? Making strings, throwing projectiles and catching small game during Marine Isotope Stage 4 (Abri du Maras, France). Quaternary Science Reviews, 82, p. 23-40.

Hockett B.S. 1989 - Archaeological Significance of Rabbit-Raptor Interactions in Southern California. North American Archaeologist, 10, p. 123-139.

Hockett B.S. 1991 - Toward distinguishing human and raptor patterning on leporid bones. American Antiquity, 56, p. 667-679.

Hockett B.S. 1995 - Comparison of leporid bones in raptor pellets, raptor nests, and archaeological sites in the Great Basin. North American Archaeologist, 16, p. 223-238.

Hockett B.S. 1996 - Corroded, Thinned and Polished Bones Created by Golden Eagles (Aquila chrysaetos): Taphonomic Implications for Archaeological Interpretations. Journal of Archaeological Science, 23, p. 587-591.

Hockett B.S. et Bicho N.F. 2000 - The Rabbits of Picareiro Cave: Small Mammal Hunting During the Late Upper Palaeolithic in the Portuguese Estremadura. Journal of Archaeological Science, 27, p. 715-723.

Hockett B. et Haws J.A. 2002 - Taphonomic and Methodological Perspectives of Leporid Hunting During the Upper Paleolithic of the Western Mediterranean Basin. Journal of Archaeological Method and Theory, 9, p. 269-302.

Huguet-PÀmies R. 2007 - Primeras ocupaciones humanas en la Península Ibérica : Paleoeconomía en la Sierra de Atapuerca (Burgos) y la Cuenca de Guadix-Baza (Granada) durante del Pleistoceno Inferior. Tarragona : Universitat Rovira i Virgili, 2007. 569 p. Tesis doctoral.

JAUBERT J., KERVAZO B., BAHAIN J.-J., BRUGAL J.-P., CHALARD P., FALGUERES C., JARRY M., JEANNET M., LEMORINI C., LOUCHART A., MAKSUD F., MOURRE V., QUINIF Y. et THIEBAUT C. 2005 - Coudoulous I (Tour-de-Faure, Lot), site du Pléistocène moyen en Quercy : Bilan pluridisciplinaire. In : N. Molines, M.-H. Moncel, J.-L. Monnier (Ed.), Les premiers peuplements en Europe: Données récentes sur les modalités de peuplement et sur le cadre chronostratigraphique, géologique et paléogéographique des industries du Paléolithique ancien et moyen en Europe. Oxford : BAR, International Series, 1364, p. 237-251

JEANNET M. 2005 - La microfaune de l'Igue des Rameaux à Saint-Antonin-Noble-Val (Tarn-etGaronne, France). Essai de Biostratigraphie. Préhistoire du Sud-Ouest, 12, p. 109-125. 
Jones E.L. 2006 - Prey choice, mass collecting, and the wild European rabbit (Oryctolagus cuniculus). Journal of Anthropological Archaeology, 25, p. 275-289.

Koby F. 1959 - Contribution au diagnostic ostéologique différentiel de Lepus timidus et Lepus europaeus. Verhandlungen der Naturforschenden Gesellschaft, 70, p. 19-44.

LANGLAIS M., COSTAMAGNO S., LAROULANDIE V., PÉTILLON J.-M., DISCAMPS E., MALLYE J.-B., COCHARD D. and KUNTZ D. 2012 - The evolution of magdalenian societies in South-West France between 18,000 and 14,000 cal BP: changing environments, changing tool kits. Quaternary International, 272-273, p. 138-149.

Lloveras L., Moreno-García M. et Nadal J. 2008a - Taphonomic analysis of leporid remains obtained from modern Iberian lynx (Lynx pardinus) scats. Journal of Archaeological Science, 35, p. 1-13.

Lloveras L., Moreno-Garcia M. et Nadal J. 2008b - Taphonomic study of leporid remains accumulated by the Spanish Imperial Eagle (Aquila adalberti). Geobios, 41, p. 91-100.

Lloveras L., Moreno-Garcia M. et Nadal J. 2009 - The eagle owl (Bubo bubo) as a leporid remains accumulator: taphonomic analysis of modern rabbit remains recovered from nests of this predator. International Journal of Osteoarchaeology, 19, p. 573-592.

Lloveras L., Moreno-García M. et Soler N. 2010 - The application of actualistic studies to assess the taphonomic origin of Musterian rabbit accumulations from Arbreda Cave (North-East Iberia). Archaeofauna, 19, p. 99-119.

Lloveras L., Moreno-Garcia M. et Nadal J. 2012 - Feeding the Foxes: An Experimental Study to Assess Their Taphonomic Signature on Leporid Remains. International Journal of Osteoarchaeology, 22, p. 577-590.

LÓpez-MartÍnez N. 1980 - Les lagomorphes (Mammalia) du Pléistocène supérieur de Jaurens. Nouvelles Archives du Muséum d'Histoire Naturelle de Lyon, 18, p. 1-16.

Mallye J.-B., Cochard D. et Laroulandie V. 2008 - Accumulations osseuses en périphérie de terriers de petits carnivores : les stigmates de prédation et de fréquentation. Annales de Paléontologie, 94, p. 187-208.

MarfÀ DE R. 2009 - Els lagomorfs (O. Lagomorpha;Cl. Mammalia) del Pliocè i Pleistocè europeus. Barcelone : Universitat de Barcelona, 2009. 206 p. Tesi doctoral.

Maul L. 2014 - Leporid remains of the Sesselfelsgrotte (Neuessing, Lower Bavaria). In : G. Freund, L. Reisch (Ed.), Sesselfelsgrotte VI : Naturwissenschaftliche Untersuchungen. Wirbeltierfauna 1.

Stuttgart : Franz Steiner Verlag Wiesbaden, p. 119-139.

Maureille B. et Vandermeersch B. 2007 - Les sépultures néandertaliennes. In : B. Vandermeersch, B. Maureille (Ed.), Les Néandertaliens, Biologie et Cultures. Paris : Documents Préhistoriques, C.T.H.S, p. 311-322.

Maurin H. et Haffner P. 1995 - Inventaire de la faune de France. Paris : Nathan, 415 p.

Morel P. et Müller W. 1997 - Un Campement magdalénien au bord du lac de Neuchâtel : étude archéozoologique (Hauterive-Champréveyres, 11). Neuchâtel: Archéologie Neuchâteloise, 23, 152 p.

Morin E. 2012 - Reassessing Paleolithic Subsistence: The Neandertal and Modern Human Foragers of Saint-Césaire. New Yorkity Press, 350 p.

Palacios F. et López-MartÍnez N. 1980 - Morfología dentaria de las liebres europeas (Lagomorpha, Leporidae). Doñana. Acta Vertebrata, 7, p. 61-81. 
Patnaik R. 2002 - Pliocene Leporidae (Lagomorpha, Mammalia) from the Upper Siwaliks of India: Implications for Phylogenetic Relationships. Journal of Vertebrate Paleontology, 22, p. 443-452.

Pavao B. et Stahl P.W. 1999 - Structural Density Assays of Leporid Skeletal Elements with Implications for Taphonomic, Actualistic and Archaeological Research. Journal of Archaeological Science, 26, p. 53-66.

Payne S. 1983 - Bones from cave sites: Who ate what? Problems and a case study. In: J. CluttonBrock, C. Grigson (Ed.), Animals and Archaeology: 1. Hunters and Their Prey. Oxfordal Series, 163, p. $149-162$.

Pelletier M., Cochard D., Boudadi-Maligne M., Crochet J.-Y. et Bourguignon L. 2015 - Lower Pleistocene leporids (Lagomorpha, Mammalia) in western Europe: new data from Bois-de-Riquet (Lézignan-la-Cèbe, Hérault, France). Comptes Rendus Palévol, 14, p. 371-385.

PÉrez Ripoll M. 1993 - Las marcas tafonómicas en huesos de lagomorfos. In : P. Fumanal, J. Bernabeu (Ed.), Estudios Sobre El Cuaternario. Medios Sedimentarios. Cambios Ambientales. Habitat Humano. Valencia : Universidad de Valencia, AEQUA, p. 227-231.

PÉrez Ripoll M. 2004 - La consommation humaine des lapins pendant le Paléolithique dans la région de Valencia (Espagne) et l'étude des niveaux gravettiens de La Cova de les Cendres (Alicante). In : J.-P. Brugal, J. Desse (Ed.), Petits animaux et Sociétés humaines. Du complément alimentaire aux ressources utilitaires. XXIVe Rencontres Internationales d'Archéologie et d'Histoire d'Antibes. Antibes, APDCA, p. 191-206.

RodrÍguez-Hidalgo A., SaladiÉ P., Marín J. et Canals A. 2015 - Expansion of the referential framework for the rabbit fossil accumulations generated by Iberian lynx. Palaeogeography, Palaeoclimatology, Palaeoecology, 418, p. 1-11.

Rouzaud F., Soulier M., Brugal J.-P. et Jaubert J. 1990 - L'Igue des Rameaux (Saint-Antonin-NobleVal, Tarn-et-Garonne). Un nouveau gisement du Pléistocène moyen : premiers résultats. Paleo, 2, p. 89-106.

Sanchis-Serra A. 2000 - Los restos de Oryctolagus cuniculus en las tafocenosis de Bubo bubo y Vulpes vulpes y su aplicación a la caracterización del registro faunístico arqueológico. Saguntum, 32, p. 31-50.

Sanchis-Serra A. 2010 - Los Lagomorphos del Paleolitico Medio de la region central y suboriental del Mediterraneo Ibérico, Caracterizacion tafonomica y taxonomica. València : Universitat de València, 2010. 605 p. Tesis doctoral.

Sanchis-Serra A. 2012 - Los lagomorfos del Paleolítico medio en la vertiente mediterránea ibérica : Humanos y otros predadores como agentes de aporte y alteración de los restos óseos en yacimientos arqueológicos. Valenciaistórica - Museo de Prehistoria de Valencia, 271 p.

Sanchis-Serra A. et Fernandez Peris J. 2008 - Procesado y consumo antrópico de conejo en la Cova del Bolomor (Tavernes de la Valldigna, Valencia). El nivel XVIIc (ca $350 \mathrm{ka}$ ). Complutum, 19, p. 25-46.

Schmitt D.N. 1995 - The taphonomy of Golden Eagle prey accumulations at Great Basin roosts. Journal of Ethnobiology, 15, p. 237-256.

Schmitt D.N. et Juell K.E. 1994 - Toward the Identification of Coyote Scatological Faunal Accumulations in Archaeological Contexts. Journal of Archaeological Science, 21, p. 249-262.

Sharples C.M., Fa J.E. et Bell D.J. 1996 - Geographical variation in size in the European rabbit Oryctolagus cuniculus (Lagomorpha: Leporidae) in western Europe and North Africa. Zoological Journal of the Linnean Society, 117, p. 141-158. 
Simard S. 1968 - Etude paléontologique et paléoclimatique de la microfaune du Régourdou (Montignac, Dordogne, France). Naturaliste canadien, 95, p. 1435-1457.

Stamatis C., Suchentrunk F., Moutou K.A., Giacometti M., Haerer G., Djan M., Vapa L., Vuković M., Tvrtković N., Sert H., Alves P.C. et Mamuris Z. 2009 - Phylogeography of the brown hare (Lepus europaeus) in Europe : a legacy of south-eastern Mediterranean refugia ? Journal of Biogeography, 36 , p. 515-528.

Stiner M.C. 1994 - Honor among thieves: A zooarchaeological study of Neandertal ecology. Princeton : Princeton University Press, 448 p.

SZMIDT C., LAROULANDIE V., DACHARY M., LANGLAIS M. et COSTAMAGNO S. 2009 - Harfang, renne et cerf : nouvelles dates $14 \mathrm{C}$ par SMA du Magdalénien supérieur du Bassin aquitain au Morin (Gironde) et Bourrouilla (Pyrénées-Altantiques). Bulletin de la Société Préhistorique française, 106, p. 583-587.

Thulin C.-G. 2003 - The distribution of mountain hares Lepus timidus in Europe : a challenge from brown hares L. europaeus? Mammal Review, 33, p. 29-42.

Val A. et Mallye J.-B. 2011 - Taphonomie du fouilleur : influence de la maille de tamis sur la représentation anatomique des petits animaux à fourrure. In : V. Laroulandie, J.-B. Mallye, C. Denys (Ed.), Taphonomie des Petits Vertébrés : Référentiels et Transferts aux Fossiles. Actes de la Table Ronde du RTP Taphonomie (Talence 20-21 octobre 2009). Oxford : BAR International Series, p. 93-100.

VALLADAS H., CHADELLE J.-P., GENESTE J.-M., JORON J.-L., MEIGNEN L., TEXIER P.-J. 1987 Datation par la thermoluminescence de gisements moustériens du sud de la France.

L'Anthropologie, 91, p. 211-226.

Veitschegger K., FLADERER F.A. et NAGEL D. 2015 - A Late Pleistocene to Holocene succession of leporid species in the southern Vienna Basin (Austria). Comptes Rendus Palévol, 14, p. 403-410.

Vigne J.-D. et Marinval-Vigne M.-C. 1983 - Méthode pour la mise en évidence de la consommation du petit gibier. In: J. Clutton-Brock, C. Grigson (Ed.), Animals and Archaeology: 1. Hunters and Their Prey. Oxford: BAR Internationnal Series, 163, p. 239-242.

Vigne J.-D., Marinval-Vigne M.-C., De Lanfranchi F. et Weiss M.-C. 1981 - Consommation du «Lapin-rat » (Prolagus sardus Wagner) au Néolithique ancien méditerranéen Abri d'AraguinaSennola (Bonifacio, Corse). Bulletin de la société préhistorique Française, 78, p. 222-224.

Villa P. et Mahieu E. 1991 - Breakage patterns of human long bones. Journal of Human Evolution, 21, p. 27-48.

von den Driesch A. 1976 - A guide to the measurement of animal bones from archaeological sites. Harvard University : Peabody Museum of Archaeology and Ethnology, 136 p.

Yravedra Sainz de los Terreros J. 2006 - Implicaciones tafonómicas del consumo de Lagomorfos por BúhoReal (Bubo Bubo) en la interpretación de los yacimientos arqueológicos. Anales de Prehistoria y Arqueología, 22, p. 33-47.

\section{ABSTRACTS}

Since the end of the nineteenth century, a great deal of work studying subsistence patterns of prehistoric societies in Western Europe has been done. During the Middle Paleolithic, humans were interested in small game, particularly the Leporidae, taxa that were abundant in their territories. However, distinguishing the exact nature of their origin in an archaeological site is 
not an easy task, given that numerous agents could be responsible for their accumulation (i.e., natural mortality, acquisition by humans and/or other terrestrial carnivores, or even nocturnal or diurnal raptors). In this contribution, we put forth a new taphonomic and paleontological study of the leporids of Regourdou, a Mousterian site that has yielded a Neandertal skeleton. This study suggests that no predators were involved in the accumulation of the hare or rabbit remains, but rather that they are due to natural (accidental) mortality for the former, and natural (attritional) mortality for the latter. Specifically, the evidence suggests that at one point in its history (for the hares), the cavity functioned as a natural pitfall trap, while for the rabbits it appears to show the existence of a warren, which we interpret as having existed during the last occupation of the site during MIS 4 or 3 , before the end of the accumulation of sediments in the site. Morphological variation and body size of individuals also allows us to specify the order of paleoenvironmental changes since the site's functional beginning, confirming the attribution of the inferior levels to the MIS 5 temperate period, and the upper levels to a more recent phase in MIS 4 or 3.

Depuis la fin du XIX ${ }^{\mathrm{e}}$ siècle, l'Europe occidentale a fait l'objet de très nombreux travaux pour étudier les modes de subsistance des sociétés préhistoriques. À partir du Paléolithique moyen, les Hommes vont alors s'intéresser au petit gibier, tels que les léporidés, taxons relativement abondants sur ce territoire. Or, distinguer l'origine de leur accumulation dans un site archéologique ne constitue pas une tâche aisée tant les agents pouvant en être responsables sont nombreux (i.e. mortalité naturelle, humains, carnivores terrestres, rapaces nocturnes ou diurnes). Dans cette contribution, nous avons mené des études taphonomique et paléontologique sur les léporidés de Regourdou, gisement moustérien ayant livré le squelette d'un Néandertalien. Les indices recensés suggèrent qu'aucun prédateur n'est intervenu dans les processus d'accumulation des restes de lièvres et de lapins, mais leurs assemblages seraient dus, respectivement, à une mortalité naturelle de type accidentelle et de type attritionnelle. La mise en évidence du premier processus montre que la cavité aurait fonctionné comme un aven-piège à un moment donné de son histoire, tandis que le second révèle l'existence d'une Garenne in situ, interprétée comme la dernière occupation du site durant le MIS 4 ou 3, avant la fin du comblement sédimentaire. Les variations morphologiques et de taille corporelle des individus permettent également de préciser les changements d'ordre paléo-environnementaux depuis le début du fonctionnement du site, confirmant l'attribution des niveaux inférieurs à la période tempérée du MIS 5, et les niveaux supérieurs à une phase plus récente du MIS 4 ou 3.

INDEX

Mots-clés: taphonomie, paléontologie, morphométrie géométrique 2D, mortalité attritionnelle, mortalité accidentelle, Lepus timidus, Oryctolagus cuniculus

Keywords: Taphonomy, Palaeontology, 2D geometric morphometry, Attritional mortality, Accidental mortality, Lepus timidus, Oryctolagus cuniculus

\section{AUTHORS}

\section{MAXIME PELLETIER}

Aix Marseille Université, CNRS, Ministère de la culture et de la communication, LAMPEA UMR 7269, FR-13094 Aix-en-Provence - maxime.pelletier@etu.univ-amu.fr ou pelletiermaximus@gmail.com 


\section{AURÉLIEN ROYER}

Université de Bourgogne, Biogéosciences, UMR CNRS 6282, 6 Boulevard Gabriel, FR-21000 Dijon ; École Pratique des Hautes Études, Laboratoire EPHE PALEVO, FR-21000 Dijon -

aurelien_royer@hotmail.com

\section{TRENTON HOLLIDAY}

Departement of Anthropology 101 Dinwiddie Hall Tulane University New Orleans, Louisiana 70118 USA; Evolutionary Studies Institute University of the Witwatersrand Private Bag 3, Wits 2050 Republic of South Africa - hollid@tulane.edu

\section{BRUNO MAUREILLE}

CNRS, Université de Bordeaux, Ministère de la culture et de la communication, PACEA UMR 5199, FR-33615, Pessac - b.maureille@pacea.u-bordeaux1.fr 